\title{
Sinfonia n 4 de Villa-Lobos: a vitória, a derrota e a volta por cima
}

Villa-Lobos's Fourth Symphony: the victory, the defeat, and the comeback

Paulo de Tarso Salles ${ }^{1}$

Universidade de São Paulo ptsalles@usp.br 


\section{Resumo}

O propósito deste trabalho é apresentar uma análise da Sinfonia n 4 ("A Vitória") de Heitor Villa-Lobos (1887-1959) a partir de sua estrutura formal e narrativa. $A$ obra foi composta em 1919 para celebrar o final da primeira guerra mundial, e sua estreia foi programada para um concerto dedicado ao casal real belga que visitava o Brasil em 1920.

Originalmente estruturada como um poema sinfônico em três partes, a obra se baseia em texto escrito por Luís Gastão d'Escragnolle Dória (1869-1948). A narrativa literária é recoberta por outra, de caráter musical, estruturada em forma cíclica segundo o método de Vincent d'Indy. A análise irá buscar pontos de aproximação e afastamento entre as narrativas literária e musical, segundo teorias de narratividade propostas por Eero Tarasti (1994) e Byron Almén (2008), além de análises tópicas, segundo Leonard Ratner (1980), Wye Allanbrook (1983), Raymond Monelle (2000; 2006) e outros. O objetivo é interpretar os aspectos musicalmente significativos resultantes da intertextualidade entre música e texto.

Palavras-chave: Villa-Lobos. Sinfonia. Narratividade. Teoria das tópicas. Análise musical.

\section{Abstract}

The purpose of this paper is to present an analysis of Symphony No. 4 (The Victory) by Heitor Villa-Lobos (1887-1959), from formal and narrative perspective. The work was composed in 1919 to celebrate the end of the First World War. Its premiere was planned to a concert in honor of the king and queen of Belgium, who visited Brazil in 1920.

Symphony No. 4 is based on a text written by Luís Gastão d'Escragnolle Dória (1869-1948), so it was originally a symphonic poem. The literary narrative is covered by another, of a musical character, structured in a cyclic form according to the method of Vincent d'Indy. The analysis search for points of closure and detachment among literary and musical narratives, according to theories of narrativity advanced by Eero Tarasti (1994) and Byron Almén (2008), as well musical topic analysis, after Leonard Ratner (1980) Wye Allanbrook (1983), and Raymond Monelle $(2000,2006)$ among others. My goal is to interpret the musically meaningful aspects resulting from intertextuality between music and text.

Keywords: Villa-Lobos. Symphony. Narrativity. Topics theory. Musical analysis.

1 Paulo de Tarso Salles nasceu em São Paulo. Leciona matérias teóricas no Departamento de Música da Universidade de São Paulo, onde coordena o Simpósio Villa-Lobos (http://9qtrmpbsu2v.webhostusp.sti.usp.br/). É autor dos livros Os quartetos de cordas de Villa-Lobos: forma e função (Edusp, 2018); Villa-Lobos, processos composicionais (Ed. Unicamp, 2009); Aberturas e impasses: a música no pós-modernismo e seus reflexos no Brasil (1970-1980) (Ed. Unesp, 2005); e organizou, com Norton Dudeque o livro Villa-Lobos, um compêndio: novos desafios interpretativos (Ed. UFPR, 2017). Coordena o PAMVILLA (Perspectivas Analíticas sobre a Música de Villa-Lobos), grupo de pesquisa cadastrado no CNPq. 


\section{Introdução}

A Sinfonia no 4 é uma obra com características comuns ao primeiro (1900-1917) e ao segundo (1918-1929) período criativo de Villa-Lobos (SALLES, 2009, p. 14). Os elementos presentes nessa obra que a associam ao primeiro período são o uso da forma cíclica ${ }^{2}$ e a presença de um roteiro literário estabelecendo uma narrativa prévia ao discurso musical, à maneira de um poema sinfônico. Com relação aos aspectos que caracterizam o segundo período, podemos mencionar o uso de ostinati, alguns com elementos indígenas ou afro-brasileiros e a superposição de camadas texturais com grande independência entre si. A presença desses elementos da segunda fase afeta o caráter formal da sinfonia, aproximando-a do estilo encontrado em obras posteriores, como alguns dos Choros orquestrais e Bachianas Brasileiras 3 .

Essa sinfonia pertence a um conjunto de três, juntamente com a Terceira e a Quinta sinfonias. Todas estão relacionadas ao concerto em homenagem aos Reis Alberto I e Elizabeth da Bélgica em 30 de setembro de 1920, convidados pelo presidente brasileiro Epitácio Pessoa para celebrar o tratado de paz de Versalhes e formalizar intercâmbio comercial entre os países.

A Sinfonia no 3 ("A Guerra"), também composta em 1919, teve papel decisivo na carreira do compositor, chamando a atenção do público carioca após sua estreia em 31 de julho de 1919, no concerto em "Homenagem ao Embaixador da Paz", Epitácio Pessoa ${ }^{4}$. Três compositores foram convidados a escrever música a partir de argumentos escritos por Luís Gastão d'Escragnolle Dória5, com os títulos "A guerra", "A vitória" e "A paz". Villa-Lobos recebeu a encomenda dessa obra por acaso, quando Alberto Nepomuceno desistiu de participar por causa de desentendimento com um dos organizadores do evento. Chamado de última hora, Villa-Lobos conseguiu concretizar a obra, que foi considerada a mais feliz do programa, ao lado das sinfonias "A vitória" de João Octaviano Gonçalves e "A paz" de Francisco Braga.

Estimulado pela boa recepção da obra, Villa-Lobos não só conseguiu fazer estrear sua Primeira Sinfonia ("O imprevisto", 1916) com regência do famoso maestro italiano Gino Marinuzzi (em setembro de 1919), como também decidiu compor suas próprias versões para "A vitória" e "A paz", destinadas ao concerto dedicado aos reis belgas no ano

\footnotetext{
2 A forma cíclica consiste basicamente na organização de uma obra em vários movimentos, onde um ou mais temas são apresentados no primeiro movimento e reaparecem sucessivamente nos demais. Cada movimento acrescenta novos temas que também podem reaparecer posteriormente, de modo que o último movimento é uma síntese de toda a obra. Esse tipo de organização formal foi desenvolvido a partir de Franz Liszt (1811-1886) com desdobramento na França, a partir de César Franck (1822-1890). 0 método foi sistematizado por Vincent d'Indy (1851-1931) no Cours de Composition Musicale (1909). Villa-Lobos conheceu esse livro em 1914, por meio do compositor e pianista Godofredo Leão Veloso (1859-1926).

3 John Enyart faz uma análise formal das sinfonias de Villa-Lobos, em sua tese de doutorado (ENYART, 1984). Em relação às Sinfonias $n^{\circ}$ 3e $n^{\circ} 4$, ele não considera a relação com o programa escrito, tratando as obras como casos de "música pura". O esforço de Enyart é notável, porque ele não contava àquela época com gravações dessas obras, exceto justamente a (boa) gravação da Sinfonia n 4 feita por Villa-Lobos em 1955.

4 Segundo Luciana Fagundes, o político e jurista paraibano Epitácio Pessoa (1865-1942) "alcançou notoriedade por sua atuação no Congresso e também pelo fato inusitado de ter sido eleito presidente da República enquanto atuava como representante brasileiro na Conferência da Paz" (FAGUNDES, 2018, p. 164-165).
} 
seguinte. Após uma audiência com Epitácio Pessoa, ficou decidido que apenas a Terceira e a Quarta Sinfonias seriam apresentadas naquele concerto ${ }^{6}$. O otimismo de Villa-Lobos, com relação ao sucesso dessa apresentação, é evidente em entrevista da época:

[...] pela vitória que obtive na execução da minha primeira sinfonia (A Guerra), espero a paz com a segunda (A Vitória), assim como prevejo a minha independência, quando se executar a terceira sinfonia, A Paz (Villa-Lobos, entrevista, in: A Noite, Rio de Janeiro, 30 Set. 1920).

No entanto, o compositor amargou uma grande frustração com esse concerto. $O$ rei Alberto saiu prematuramente do teatro após a apresentação de "A Guerra", levando consigo o presidente Epitácio Pessoa e praticamente toda a plateia. A notícia no Jornal do Commercio não explica as razões do incidente.

S.S. M.M. Reaes chegaram ao Municipal às 9:49 em companhia do Sr. Presidente da República e assistiram à execução do concerto cujo programa foi o seguinte:

Hymnos: Nacional Belga e Nacional Brasileiro, orchestra e coro; Francisco Braga, Oração pela Pátria, coros feminino e solo pela sra. Hedy Iracema; E. Pereira, Calabar, intermédio; Henrique Oswald, Bebê s'endort, berceuse para instrumentos de arco; Nepomuceno, Anoitece [...]; Villa-Lobos, A guerra, poema sinfônico.

Não foi executado o poema $A$ victoria por terem-se retirado S.S. M.M. e o Sr. Presidente e haver o público abandonado o recinto do teatro. (Jornal do Commercio, sexta-feira, 1 out. 1920).

Embora o motivo para a saída prematura do monarca não tenha sido esclarecido (é bem possível que o rei estivesse cansado, devido a agenda cheia de compromissos desde a manhã daquele dia), parte da imprensa preferiu atribuir isso à suposta má qualidade musical. Segundo essa visão, a atitude do rei foi interpretada como decorrente de uma questão estética, tornando o que seria uma noite de triunfo para Villa-Lobos em um significativo revés profissional e artístico. Os elementos mais audaciosos da Sinfonia $n$ o 3, que haviam sido louvados em 1919, foram interpretados negativamente no ano seguinte; e a Sinfonia no 4 não foi apresentada, desperdiçando os esforços empenhados nos ensaios para aquele concerto ${ }^{7}$. Além desse revés pessoal, a própria autoestima nacional foi abalada e para os críticos conservadores a explicação só poderia ser atribuída aos exageros "futuristas" da música villalobiana. Bastos Tigre ${ }^{8}$, em sua coluna no Correio

\footnotetext{
$6 \quad$ A audiência de Villa-Lobos com o presidente Epitácio Pessoa ocorreu em 19 ago. 1919, segundo o Correio da Manhã (20 ago. 1919). Em entrevista ( $A$ Noite, 30 set. 1920), Villa-Lobos conta que teve "a honra de ser chamado em palácio para tal fim [apresentar as sinfonias no concerto em homenagem ao rei belga], aonde expus ao Exmo. Sr. Presidente o que era o meu trabalho [...], no propósito de um espetáculo completo, não só por se tratar de três sinfonias que simbolizavam três fases interessantes para SS. MM. [...]. Lisonjeado por tal distinção, não olhei o lado prejudicial artístico, na ausência da minha última sinfonia 'A Paz'."

7 Fagundes (2007, p. 177) conta que a orquestra reunia "120 professores de orquestra e 40 músicos das bandas marciais da Polícia e Corpo de Bombeiros".

8 Manoel Bastos Tigre (1882-1957) foi poeta, compositor, jornalista, bibliotecário e publicitário, que muitas vezes adotava o pseudônimo "Dom Xiquote" para satirizar as personalidades da época. Dentre suas produções há curiosidades como o jingle "Chopp em garrafa", feito em parceria com Ari Barroso, gravado por Orlando Silva; a controversa autoria dos versos para o anúncio do "Rhum Creosotado" é atribuída a ele ou a Olavo Bilac (MIGALHAS, 2013; Correio da Manhã, 3 ago. 1957).
} 
da Manhã, ironiza o incidente de maneira curiosa; para ele, o rei Alberto, um "amigo da natureza", não suportou as "várias sinfonias futuristas, de arrancar o couro às caixas e aos bumbos", preferindo ir à Tijuca para "ouvir música" e fugir do "sinfônico barulho" (BASTOS TIGRE, 1920).

Àquela época Villa-Lobos já havia travado contato com Arthur Rubinstein (18871982), renomado pianista polonês em turnê pela América do Sul que reconheceu seu talento e se dispôs a ajuda-lo na divulgação de sua obra e na busca por apoio financeiro, público e privado, para ir a Paris (KATER, 1987); o fracasso da estreia da Sinfonia $n \circ 4$ precisava ser rapidamente superado e esquecido ${ }^{9}$. No ano de 1921 ele manteve atividade intensa, compondo novas obras e organizando concertos para apresentá-las. Destacam-se os concertos no Teatro São Pedro (em 13 de junho) ${ }^{10}$ e no Salão Nobre do Jornal do Commercio (em 21 de outubro) ${ }^{11}$. Além disso, intérpretes importantes no cenário internacional incluíram obras de Villa-Lobos em concertos no Brasil e no exterior ${ }^{12}$.

A participação bem-sucedida na Semana de Arte Moderna em São Paulo (fevereiro de 1922) ajudou o compositor a ampliar sua rede de contatos com mecenas paulistas e o integrou definitivamente ao movimento modernista, ao lado de Mario de Andrade, Tarsila do Amaral e Oswald de Andrade. Ainda em 1922, em 12 de dezembro, Villa-Lobos estreou a Quarta Sinfonia no Teatro Municipal do Rio de Janeiro ${ }^{13}$, dentro da série de concertos que organizou como uma retrospectiva de sua obra e que serviram como justificativa ao apoio buscado junto ao Congresso Nacional para sua ida a Paris em 1923, como representante oficial da música brasileira. A Quinta Sinfonia ("A Paz") permaneceu inédita e sua partitura está perdida; há pesquisadores, como Lisa Peppercorn (1991, p. 86-87, nota 7) ou Fabio Zanon (2013, p. 2) ${ }^{14}$, que chegam até mesmo a duvidar que essa obra tenha sido composta de fato.

9 O fato foi suprimido da biografia do compositor escrita por Vasco Mariz e publicada pela primeira vez em 1949. Mariz faz um registro contraditório dessa sinfonia: inicialmente ele revela que "o concerto redundou indiscutivelmente num sucesso" com direito a condecoração oferecida pelo rei e recusada pelo compositor (MARIZ, 1989, p. 63-64); mais adiante, no capítulo dedicado às sinfonias, ele comenta que "a de $n^{\circ} 4$ só foi estreada em 1955" na França (MARIZ, op. cit., p. 147). 0 relato de Guimarães (1972, p. 48-49) é vago, mencionando "cortes feitos nas duas outras peças", além da exclusão da sinfonia "A Paz" do programa.

10 O concerto teve como atração principal a segunda parte, em que foi apresentado o "Prelúdio" e o $3^{\circ}$ e $4^{\circ}$ atos da ópera Izaht, com participação do tenor Vicente Celestino (como "Conde Makian"). A data e local do evento foram alterados em cima da hora pela organização do Teatro Municipal do Rio de Janeiro, que no dia 11 de junho teve de ceder o espaço a uma Companhia Lírica visitante (Correio da Manhã, 10 jun. 1921 ). Mesmo tendo de renunciar ao sábado, o concerto realizado na segunda-feira no Teatro São Pedro teve bom público (talvez por causa da presença de Celestino), inclusive com o comparecimento do presidente Epitácio Pessoa (GUIMARÃES, 1972, p. 53). O São Pedro foi rebatizado e atualmente é o Teatro João Caetano, localizado na Praça Tiradentes.

11 O concerto foi em homenagem a Laurinda Santos Lobo (1878-1946), mecenas da Belle Époque carioca, a quem o Quatuor (1921, para coro feminino, flauta, sax alto, celesta e harpa) foi dedicado. O programa contém várias obras reapresentadas na Semana de Arte Moderna em São Paulo, quatro meses depois.

12 A soprano Vera Janacopoulos apresentou as três Miniaturas para canto e piano na Salle des Agriculteurs em Paris (21 mai. 1921 ) e 0 célebre regente italiano Gino Marinuzzi (que já havia estreado dois movimentos da Sinfonia no 1 em 1919) regeu o "Prelúdio" de Izaht no Municipal do Rio de Janeiro (2 ago. 1921).

13 Isso torna ainda mais intrigante a inconsistência do relato de Vasco Mariz a respeito da Sinfonia $n^{\circ}$ 4, provavelmente fruto da "ilusão biográfica" decorrente da relação entre biógrafo e biografado, como observa Paulo Guérios (2009, p. 28-29).

14 O texto de Zanon está no livreto que acompanha o CD com a gravação de Isaac Karabtchevsky regendo a OSESP. 


\section{Os aspectos narrativos da Sinfonia no 4}

\section{O argumento escrito por Dória é o seguinte:}

Ainda a guerra, ainda a convulsão do planeta convertido em matadouro de povos.

Passam-se anos, a peleja continua.

Abrange os quatro elementos, a terra, o ar, o fogo, a água. A Europa é cemitério de covas incertas.

O homem da Índia vem morrer ao lado do homem da Austrália, o africano sepulta-se junto do canadense.

Entre os fumos da guerra, quando um pouco dissipados, aparece a figura da vitória, correndo por entre os combatentes, animando-os, nas mãos palma virente.

Corre à França, pede-lhe com as notas da Marselhesa, arraste a flor do universo.

Corre à Itália, pede-lhe que não deixe afundar nas águas Veneza, o "cisne eterno".

Corre aos combatentes das trincheiras, dos oceanos e dos ares, levanta-lhes a coragem, promete-lhes a hora de ouro do triunfo.

Anima os vivos, pranteia os mortos.

Beija a fronte dos que avançam, chora sobre os que tombam.

Cinge ao peito os feridos, corre a consolar as mães, as irmãs, as noivas soluçantes buscando cada qual delas o único ente amado, no formigueiro humano, que lenta ou rapidamente se entredevora.

É a vitória, a luminosa vestida de resplandecências, cingida de louros, de cabeça alta, de olhos abertos para o lado da luz.

É a vitória, a prometer aos homens horas de sossego, meses de labor, anos de prosperidade, enquanto $o$ arado sulque os campos, as estradas de ferro rodem e as fábricas ronquem.

É a vitória asseverando que o sangue secará, que os campos de batalha se cobrirão de flores, que os rios correrão tranquilos para o mar, retalhado de quilhas úteis.

É a vitória, anunciando-se nos últimos toques de clarins, dispostos no silêncio, nas hosanas dos povos redimidos, das raças libertadas (DÓRIA, 1919).

Concebida originalmente em três partes, a Sinfonia $n \circ 4$ teve um movimento adicionado (o "Andante" foi acrescentado provavelmente nos anos 1940) e a gravação feita 
pelo compositor em Paris (1955) contém os quatro movimentos atuais ("Allegro impetuoso", "Andantino", "Andante" e "Lento-Allegro")15. Alguns temas da Sinfonia n 3 reaparecem ao longo da Quarta, dando a entender que Villa-Lobos imaginava uma estrutura cíclica expandida entre as três sinfonias, supondo que a Quinta tenha de fato sido elaborada em algum momento.

As correspondências e afastamentos entre as narrativas literária e musical serão analisadas de acordo com a proposta de Almén (2008), considerando os dois sistemas narrativos como "irmãos", ou seja, sem uma hierarquia preestabelecida. Apesar de o texto preceder a música, a narrativa sonora se estabelece segundo seus próprios parâmetros, que dialoga livremente e ocasionalmente pontua a narrativa escrita. Uma das estratégias usadas para a compreensão das propriedades narrativas da música é sua estrutura formal e temática, onde os elementos musicais assumem funções "actantes", como se fossem personagens dentro de uma trama organizada em função do desdobramento sonoro. As referências usadas para tratar da forma cíclica são d'Indy (1909), Wheeldon (2005) e Moortele (2009). A teoria de sonata é consultada a partir dos trabaIhos de Caplin (1998) e Hepokoski e Darcy (2006); quanto a utilização da forma sonata por Villa-Lobos, há um estudo detalhado de seus quartetos de cordas (SALLES, 2018).

As transformações sofridas pelos temas musicais ao longo de uma obra em larga escala afetam seu status e função dentro da forma, sendo um gerador da "dramaturgia musical" que "recobre a distribuição das tensões na evolução do processo sonoro" (STOÏANOVA, 2000, p. 10). A flutuação da funcionalidade temática é um dos determinantes da narrativa musical. Eero Tarasti propõe um sistema semiótico baseado em modalidades greimasianas que alternam o "ser" e o "fazer"16, como funções expressivas dentro do discurso musical:

Quando o objeto da análise é um texto musical representando a forma sonata, podemos distinguir os seguintes topoi: 1 . Áreas temáticas, lugares onde os temas-atores se movem [...]. Áreas temáticas são [...] caracterizadas por certas modalidades. 2. Transição entre áreas temáticas, mantendo o aspecto processual da música. [...] A modalidade fundamental das transições é 'tornar-se'. 3. Desenvolvimentos constituem áreas de ação musical cuja modalidade é "fazer" (TARASTI, 1994, p. 116).

Outro aspecto que contribui para a atribuição de significados dentro da narrativa musical é a presença de figuras conhecidas como "tópicas musicais", conceito delineado por Leonard Ratner (1980) para analisar a recorrência de signos sonoros surgidos em determinado contexto (dança, militar, caça, religião etc.). As tópicas musicais carregam seu significado simbólico quando deslocadas de seu contexto original, afetando a narrativa musical diante da oposição entre figuras musicais e as referências que despertam

\footnotetext{
15 Segundo Mariz (1989, p. 65-66) Villa-Lobos conheceu Vincent d'Indy pessoalmente durante sua visita a Paris em 1923, quando teria sido aconselhado "a fazer algumas modificações na $3^{\mathrm{a}}$ e $4^{\text {a }}$ Sinfonias". É possível que o acréscimo de um movimento a cada uma dessas sinfonias possa ter sido sugestão de d'Indy, mas não se sabe quando isso ocorreu. No concerto de 31 out. 1940 no Teatro Colón em Buenos Aires, a Sinfonia $n^{\circ} 3$ foi apresentada ainda com três movimentos.

16 Tarasti adota o conceito de "sintaxe modal" proposto por Greimas (2014, p. 20-29) para tratar do "caráter circular dos deslocamentos do objeto de valor" (op. cit., p. 20) em uma narrativa.
} 
nos ouvintes, conhecedores de seu uso histórico, diante das transformações. A teoria das tópicas musicais teve muitos desenvolvimentos desde então, como o estudo de Wye Allanbrook para os elementos expressivos nas óperas de Mozart (ALLANBROOK, 1983). Raymond Monelle faz um inventário bastante extenso das tópicas militares (MONELLE, 2006). Obviamente, a Sinfonia no 4 de Villa-Lobos apresenta muitas tópicas militares, usadas para caracterizar musicalmente a guerra e dar suporte à narrativa musical. Mas a obra não se limita a esse tipo de topo musical, pois sua estrutura narrativa é complexa e envolve diversas referências que dialogam com o programa literário.

Esta análise não pretende estabelecer um paralelismo literal entre música e programa literário. Ainda que ocasionalmente possam ocorrer representações miméticas onde figuras musicais assumem movimentos, formas ou sonoridades estereotipadas inseridas no texto escrito, a proposta primária desta análise será identificar os elementos musicais que constituem uma narrativa musical. Para isso, é crucial a noção de valoração e transvaloração dada às tópicas musicais ocorrentes ${ }^{17}$. Já foi mencionada a importância das tópicas militares para a Sinfonia $n^{\circ} 4$, essa tópica tem seu valor expressivo pleno desde que os elementos musicais que a definem, suas marcações, correspondam totalmente com a figura presente em determinada passagem. Monelle chama essa situação de "tópica eufórica", dado o reforço consistente dos elementos significativos para a caracterização. À medida em que as marcações de uma tópica passam a ser alteradas, seja em intensidade, seja em caráter, temos uma "disforia"18 (MONELLE, 2000, p. 43-46).

\section{Estrutura e narrativa no primeiro movimento, "Allegro impetuoso"}

O "Allegro impetuoso" tem os elementos formais de um rondó (Quadro 1). Apesar de não apresentar a esperada estrutura de um "allegro de sonata", o primeiro movimento apresenta o tema cíclico (a), que será recorrente nos demais movimentos. Um aspecto mais incomum é que o tema (b) é formado por motivos temáticos presentes na Sinfonia $n^{\circ} 3$ (segundo e terceiro movimentos); temas da Sinfonia $n^{\circ} 3$ são recorrentes ao longo de toda a Sinfonia no 4 .

A orquestração requer vastos recursos. Além dos naipes usuais expandidos para o padrão da grande orquestra romântica, há o acréscimo de instrumentos como saxofones (soprano, alto, tenor e barítono) junto às madeiras, uma fanfarra ${ }^{19}$ (com 3 cornets, 3 bugles, 2 trompas, 2 saxhorns, 2 trombones, bombardino, 2 tubas baixo em Mib, tuba baixo em Sib e bombo), e um "conjunto interno" (requinta, saxofones soprano, alto, tenor e barítono, pandeiro, triângulo, pratos e bombo).

\footnotetext{
17 O conceito de transvaloração foi desenvolvido por James Liszka (no livro The Semiotic of Myth: A Critic Study of the Symbol, Bloomington: Indiana University Press, 1989) e adaptado por Byron Almén (2008) para a análise da narrativa musical.

18 Monelle (2000, p. 43) comenta como Mahler emprega fanfarras disfóricas, escritas "fora do tom", na Sinfonia n 3 (1893-1896).

19 O termo "fanfarra" ao longo deste trabalho irá significar tanto o toque típico de característica militar como também remeter a esse naipe acrescentado à orquestra pelo compositor.
} 


\begin{tabular}{|c|c|c|}
\hline COMP. & SEÇÃO & DESCRIÇÃO \\
\hline $1-10$ & Introdução & $\begin{array}{l}\text { 1-2: ostinato em tercinas de colcheia (em 2/2) sobre a nota Mib (trombones, } \\
\text { saxofones, piano) e caixas. } \\
\text { 3-7: fanfarra inicial, em Ré, sobre a nota pedal em Mib. Disforia: acordes au- } \\
\text { mentados e cromatismo. }\end{array}$ \\
\hline $11-31$ & A1 & $\begin{array}{l}\text { 11-23: fanfarra tema cíclico (a) (tema da vitória) em Láb. 16-19: cordas suge- } \\
\text { rem a imitação do tema (estilo erudito), porém apenas o motivo inicial. } \\
\text { 24-31: fanfarra tema cíclico (a) em Fá\#, madeiras. Disforia: harmonia. }\end{array}$ \\
\hline $32-42$ & Transição & $\begin{array}{l}\text { 32-35: trompas, Dó\#. } \\
\text { 36-39: fanfarra com surdina, Solb. } \\
\text { 40-43: fanfarra nos trompetes, ff, arpejo de Si menor. }\end{array}$ \\
\hline $42-85$ & B1 & $\begin{array}{l}\text { 42-60: tema (b), cordas em Si menor (viola + cello), com pedal em Mi; esse } \\
\text { tema reúne temas ocorrentes no I ("Allegro con brio", desenvolvimento, c. } \\
\text { 116-138); II ("Scherzo", c. 75-104) e III ("Lento e marcial", c. 99-107) movi- } \\
\text { mentos da Sinfonia } n^{\circ} 3 . \\
\text { 62-85: tema (b), violinos, em Mi menor, com pedal em Lá (tímpano). }\end{array}$ \\
\hline $85-106$ & Transição & $\begin{array}{l}\text { 85-93: fanfarra, tam-tam, em Mi; 90-95: movimento ascendente em tons } \\
\text { inteiros (harpa, piano, celesta); 96-106: melodia (Dó\#) dobrada por trompete, } \\
\text { trompa, oboé e flauta. }\end{array}$ \\
\hline $107-118$ & A2 & $\begin{array}{l}\text { Tema cíclico (a), violinos em Sol (fanfarra disfórica, cordas tocando como se } \\
\text { fossem metais). }\end{array}$ \\
\hline $119-143$ & Transição & $\begin{array}{l}\text { Novos materiais melódicos; redução de andamento e densidade. } \\
\text { 119-125: metais e madeiras, pedal em Sol, allargando. Fá - Sib. } \\
\text { 126-129: trompas e trompete ("Poco più mosso"); trombone pedal em Sol. } \\
\text { 130-143: cordas, allargando. } \\
\text { Cadência c. } 136-143: 6-z 28\left(\mathrm{I}_{2}\right), 6-\mathrm{z} 49\left(\mathrm{I}_{10}\right) \text { e } 6-30\left(\mathrm{~T}_{0,6}\right) \text {. Acordes/coleções } \\
\text { com eixo de simetria intervalar, sugerindo "repouso" dentro da sintaxe } \\
\text { villalobiana. }\end{array}$ \\
\hline $144-160$ & C & $\begin{array}{l}\text { Alteração métrica na melodia (6/4), a harmonia permanece em } 2 / 2 \text {. } \\
\text { Dinâmica do acompanhamento em pp; melodia no xilofone e flautas (ff). } \\
\text { 144-154: baixo (fagote + contrabaixo) em movimento descendente: Fá - Mi - } \\
\text { Ré; melodia e harmonia realizam sequência cromática ascendente. } \\
\text { 155-160: melodia diatônica (teclas brancas) em sequência ascendente (piano, } \\
\text { harpa, xilofone, flauta, piccolo), com glissandos; harmonia mantém sequên- } \\
\text { cia cromática ascendente; movimento descendente da linha de baixo (fagote, } \\
\text { cello e contrabaixo): Dó - Sib - Lá. }\end{array}$ \\
\hline $160-195$ & B2 & $\begin{array}{l}\text { Tema (b), variante simplificada nas cordas, reforçada pelos metais. Transpo- } \\
\text { sições sequenciais (módulo de } 4 \text { compassos): Láb-Ré\#-Sol\#-Dó\#. Sinos, c. } \\
\text { 161-173. Novo tema nos violinos (c. 174-187), ainda em escrita alla breve in- } \\
\text { terrompendo a transposição em Dó\# do tema (b); o tema (b) retorna em Sol\# } \\
\text { (c. 188-196) no registro grave (cello, contrabaixo, tuba e trombone). }\end{array}$ \\
\hline $197-204$ & A3 & Tema cíclico (a), fanfarra em Sib (do tipo "eufórico", em seu timbre de origem). \\
\hline $204-223$ & Transição & $\begin{array}{l}\text { Diluição em cânone: Si-Fá\#-Dó\#. Trítono na região grave (trombone, tuba, } \\
\text { cello e contrabaixo), Si-Fá. Harpejo aumentado (fanfarra inicial) nas madeiras. }\end{array}$ \\
\hline $224-244$ & Coda & $\begin{array}{l}\text { 224-233: fanfarra inicial, disfórica, com as cordas em Dó\# (mudança de tim- } \\
\text { bre, como em A2). } \\
\text { 234-244: tríades descendentes, de D\#m a Bm; pedal em Fá\# nos tempos } \\
\text { fracos dos compassos (piano, harpas e celesta); cadência em Si (mônada). }\end{array}$ \\
\hline
\end{tabular}

Quadro 1 - "Allegro impetuoso", estrutura formal. Fonte: elaboração do autor. 
A introdução apresenta um tema em estilo de fanfarra, tocado por madeiras e metais e com sua linha inferior dobrada pelos contrabaixos (Fig. 1) ${ }^{20}$.

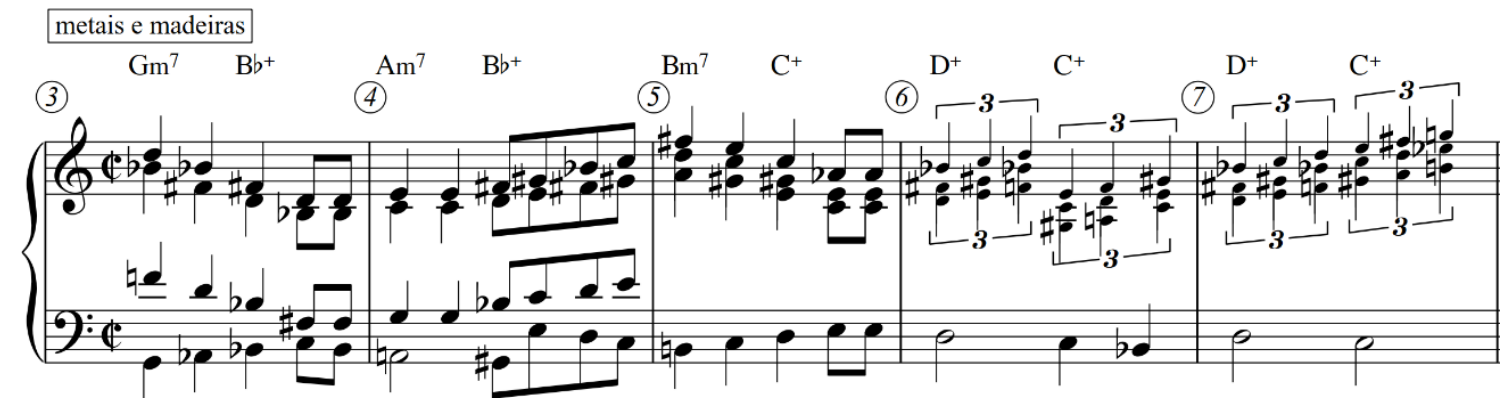

Figura 1 - "Allegro impetuoso", c. 3-7, fanfarra na Introdução. Alguns instrumentos foram omitidos. Fonte: elaboração do autor.

A fanfarra introdutória apresenta aspectos pouco comuns às fanfarras militares: o perfil melódico e harmônico não é o arpejo de um acorde maior, mas de uma tríade aumentada ${ }^{21}$; em consequência disso, sua harmonização é cromática, ao invés do diatonismo que caracteriza a tópica militar22. Um terceiro aspecto, ocorrente, mas não visualizado na Figura 1, é o ostinato rítmico em tercinas de colcheias, dentro da métrica em 2/2. Assim, podemos classificar essa fanfarra inicial como "disfórica".

A tópica militar tem como significados habituais: "euforia, masculinidade, heroísmo, aventura, evocação de feitos nobres e coragem irrefletida"3" (MONELLE, 2006, p. 142). A alteração dos elementos observada anteriormente, pode exprimir um estado de espírito diferente, condizente com o sentimento expresso pelo programa, onde a duração da guerra ("Passam-se anos, a peleja continua") altera o caráter irrefletido da coragem, trazendo outra consciência ao ver o "planeta convertido em matadouro de povos" (DÓRIA, 1919), além de boa dose de incerteza quanto ao futuro.

De qualquer modo, a "coragem" é reafirmada logo em seguida por outra fanfarra (literalmente o naipe nomeado como "fanfarra" na partitura), que apresenta o tema cíclico da vitória (tema "a"); o tema é repetido quase canonicamente pelas cordas (c. 16-19), sugerindo o "estilo erudito"24 (Fig. 2). No entanto, considerando as harmonias resultantes entre baixo e melodia, vê-se que o tema ainda está longe de expressar plenamente o sentimento de vitória proposto pelo título, o que corresponde com a narra-

20 As análises das sinfonias villalobianas, feitas por John Enyart, são às vezes inconsistentes na identificação dos temas e sua função formal, especialmente quando quer associá-los com aspectos da música brasileira, como por exemplo, quando ele destaca e comenta a linha mais grave da fanfarra introdutória (Fig. 1), que segundo ele "demonstra ambiguidade tonal" reveladora de "suas raízes na música folclórica do Brasil" (ENYART, 1984, p. 149).

21 A passagem é fortemente ancorada na coleção de tons inteiros; porém, a ocorrência da nota Lá natural altera sua estrutura, resultando no heptacorde simétrico designado por Forte (1973) como 7-33.

22 Monelle oferece uma "antologia de toques militares, principalmente do séc. XIX" (MONELLE, 2006, p. 281, tradução do autor). A totalidade dos exemplos oferecidos mostra a onipresença da tríade maior, ocasionalmente com elaborações melódicas dentro da escala diatônica; a métrica varia bastante, com fórmulas de compasso em 2/4, 6/8, 4/4, 3/2, 3/8, 6/4, 3/4, 2/2, 9/8 (op. cit., p. 282-290). Esses toques representam os casos mais "relevantes para a música de concerto e ópera no repertório consolidado" (op. cit., p. 282).

23 No original: "the signification of this topic seems euphoric, manly, heroic, adventurous, evocative of noble deeds and reckless courage" (a tradução é minha).

24 O estilo erudito (learned style) é outra tópica descrita por Ratner (1980), relacionada ao uso do contraponto em associação com gêneros "elevados" de composição, originalmente de caráter sacro. 
tiva literária. Após essa segunda afirmação hesitante da tópica militar, pode-se levantar a hipótese que a opção pela forma rondó, ao invés da forma sonata, seja um recurso narrativo que associa a recorrência dos temas e seções contrastantes ${ }^{25}$ com os percalços da guerra, seu fluxo de vitórias e derrotas em batalhas localizadas.

O próprio Villa-Lobos oferece um bom exemplo de como a transvaloração das características originais da tópica militar pode transformar a expressão musical. Um tema muito semelhante em perfil rítmico e melódico ocorre no movimento final do Carnaval das crianças (1920), "Folia de um bloco infantil"26 (Fig. 3).

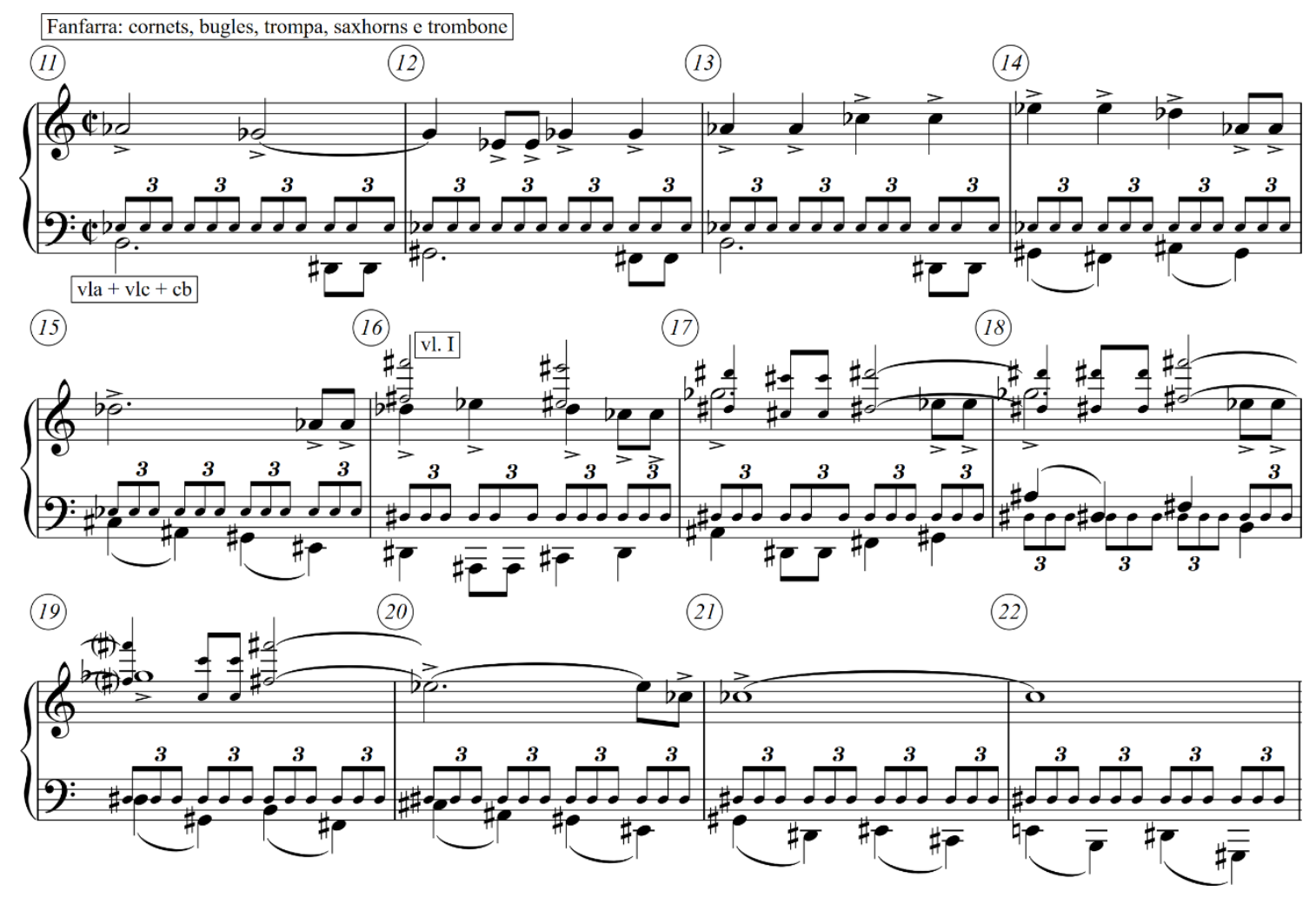

Figura 2 - "Allegro impetuoso", c. 11-22, tema (a), fanfarra. Várias partes foram omitidas. Fonte: elaboração do autor (redução).

O rondó é basicamente "a justaposição de seções discretas, cada qual normalmente marcada por ideias melodicamente memoráveis. Seu aspecto definidor é a recorrência de um refrão (ou "tema do rondó") na tonalidade tônica, separando as aparições de episódios contrastantes ou diferentes [...], os quais são frequentemente, mas não sempre, em tonalidades diferentes da tônica." (HEPOKOSKI; DARCY, 2006, p. 388, tradução minha).

26 Carnaval das crianças é uma obra para piano solo, cujo último movimento, "Folia de um bloco infantil", requer quatro mãos. Villa-Lobos posteriormente adaptou essa suíte para piano solista e orquestra, dando o título de Momoprecoce (1929). 


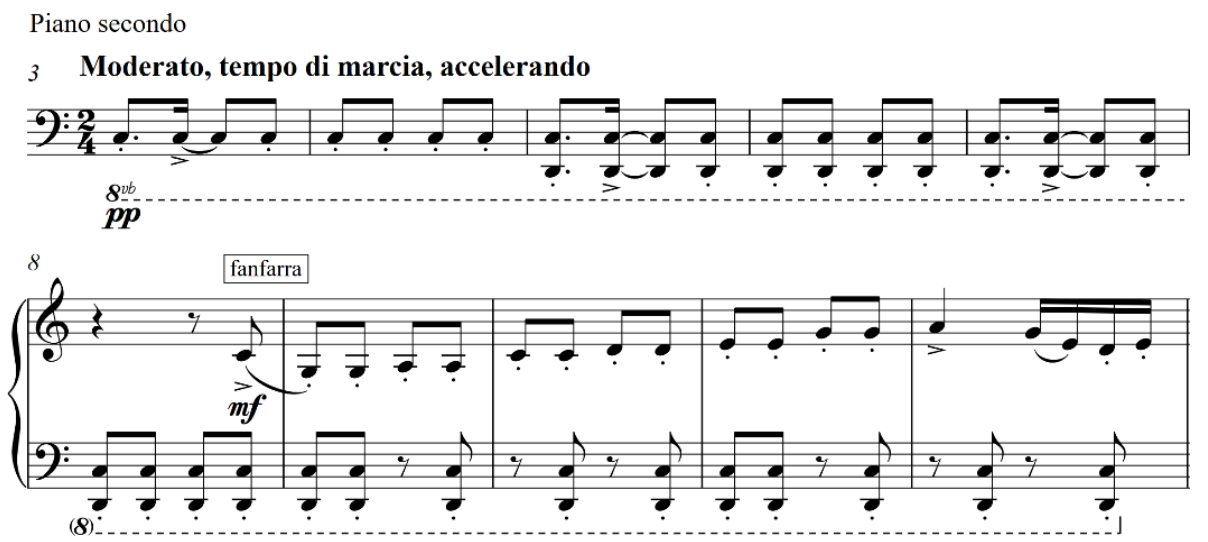

Figura 3 - Villa-Lobos: Carnaval das Crianças (1920), "Folia de um bloco infantil", c. 3-12, fanfarra. Fonte: elaboração do autor.

Há muitas semelhanças entre o "tema da vitória" da Sinfonia no 4 e a fanfarra do Carnaval das crianças, mas são suas diferenças que nos interessam mais: o caráter leve e despreocupado da "Folia de um bloco infantil" é marcado pelo ostinato simples e repetitivo, enfatizando os tempos fracos e síncopes, com início na anacruse; a articulação em staccato é outro índice de leveza e do movimento de dança durante a marcha; melodia e harmonia são claramente pentatônicas, denotando sua inocência e o estar à vontade naquele ambiente. Em oposição, o tema da vitória começa pesadamente no tempo forte; apesar de também ser pentatônico, a linha do baixo é diatônica (sugerindo Dó\# mixolídio) e seus pontos de repouso melódico são erráticos, oscilando entre Réb, Solb, Mib e Dób, sugerindo incerteza e desconforto.

A seção B (c. 42-65) emerge discretamente, submersa pela terminação de uma fanfarra tocada em $\mathrm{ff}$ pelos trompetes, arpejando a tríade de Si menor (c. 40-43). O tema (b), que demarca essa seção (Fig. 4), funde dois temas presentes em pontos diferentes da Sinfonia $n^{\circ}$ 3. O "período" inicial desse tema (c. 42-49) ${ }^{27}$ aparece no primeiro movimento (desenvolvimento) e no Scherzo (seção C) da Terceira Sinfonia; sua continuação (c. 50-ss.) ocorre no terceiro movimento (seção B) da Terceira.

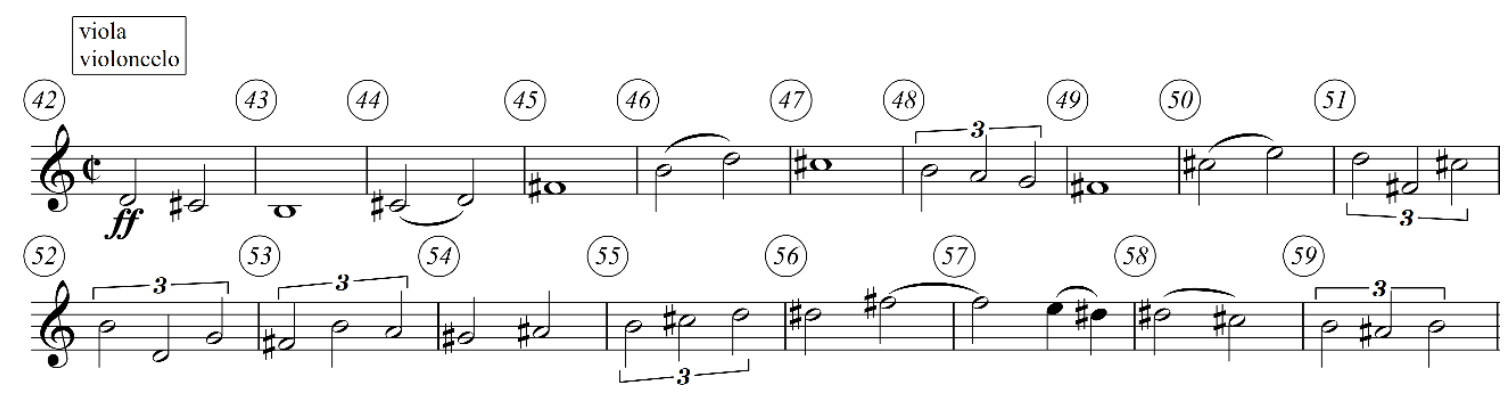

Figura 4 - "Allegro impetuoso", c. 42-59, tema (b). Fonte: elaboração do autor.

O tema (b) sugere a transição de Si menor para Si maior, embora a sustentação da nota pedal Mi (tuba, contrabaixos e tímpano) cause certa perturbação tonal. $O$ fator mais importante é seu caráter, fundado no estilo cantante, à maneira de Puccini ${ }^{28}$, com

27 Faço referência a terminologia de Caplin (1998, p. 49), que define período como "uma frase de oito compassos" que "começa com uma ideia básica de dois compassos" (tradução minha).

28 O estilo cantante (singing style) é uma das tópicas propostas por Leonard Ratner (1980, p. 9). Wye Allanbrook observa ainda a questão 
acompanhamento convencional por piano e harpas. Entretanto, ao longo de toda a seção há uma camada preenchida pelo trêmulo dos trombones e pontuações de trompas, trompetes e tímpano, deixando claro que não se trata de um contraste temático "calmo", mas uma reflexão envolvida por turbulências. O caráter do tema (b) se torna mais afirmativo quando tocado no registro médio-agudo dos violinos (c. 62-85), com notas longas sustentadas pelos metais; mesmo assim, o tímpano persiste com sua pontuação aparentemente "fora de lugar" (em Lá).

A música segue sem interrupções, em sucessão de fanfarras mais ou menos disfóricas (o caso mais evidente é a reaparição do tema cíclico nas cordas, c. 107). Um evento mais significativo é o gesto cadencial que antecede a seção C, onde Villa-Lobos emprega sua sintaxe peculiar na qual a simetria intervalar ${ }^{29}$ sugere a ideia de "repouso", reforçada pelo afrouxamento do andamento (allargando e fermata). É a primeira cadência no interior do primeiro movimento (Fig. 5).

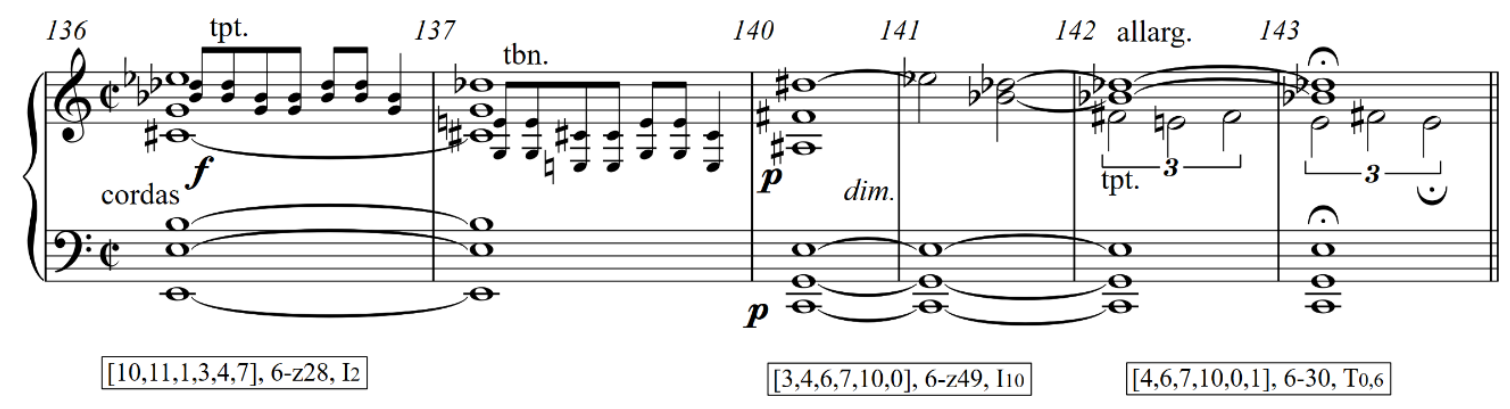

Figura 5 - "Allegro impetuoso", c. 136-143, cadência simétrica. Algumas partes foram omitidas. Fonte: elaboração do autor.

A cadência introduz a primeira mudança textural significativa, interrompendo momentaneamente as tópicas militares. No entanto, os conflitos persistem: a linha de baixo faz uma progressão diatônica no sentido descendente (Fá-Mi-Ré-Dó-Sib-Lá) em oposição ao movimento sequencial cromático ascendente da melodia (flauta e xilofone) e dos acordes; na etapa final dessa seção (c. 155-159) a melodia faz uma progressão diatônica ascendente, marcada por glissandos, enquanto os acordes seguem cromaticamente. Esses elementos podem ser dispostos esquematicamente, a partir de seus modos indicativos de qualidade e movimento (Fig. 6).

rítmica e métrica que caracteriza a melodia alla breve, escrita em valores mais longos que a semínima, aos quais ela atribui o caráter de "marcha exaltada", se referindo ao estilo operístico de Mozart (ALLANBROOK, 1983, p. 22-23). No caso de Villa-Lobos, o verismo pucciniano é uma referência mais próxima da sonoridade encontrada nas Sinfonias $n^{\circ} 3$ e $n^{\circ} 4$.

29 Os três hexacordes resultantes são indicados com a numeração de Forte: 6-z28, 6-z49 e 6-30. 0 número "6" indica sua cardinalidade, ou seja, a quantidade de alturas em cada grupo; os números "28", "49" e "30" indicam a posição na tabela Forte (1973), um algoritmo que ordena os intervalos do menor para o maior; a letra "z" indica uma propriedade - que curiosamente relaciona os hexacordes ocorrentes 28 e 49 - na qual ambos compartilham o mesmo "vetor intervalar", isto é, possuem a mesma quantidade e distribuição de intervalos, mas não estão relacionados por transposição ou inversão. Apesar desses três hexacordes serem subconjuntos da coleção octatônica, suas alturas específicas não apontam para essa formação escalar. 


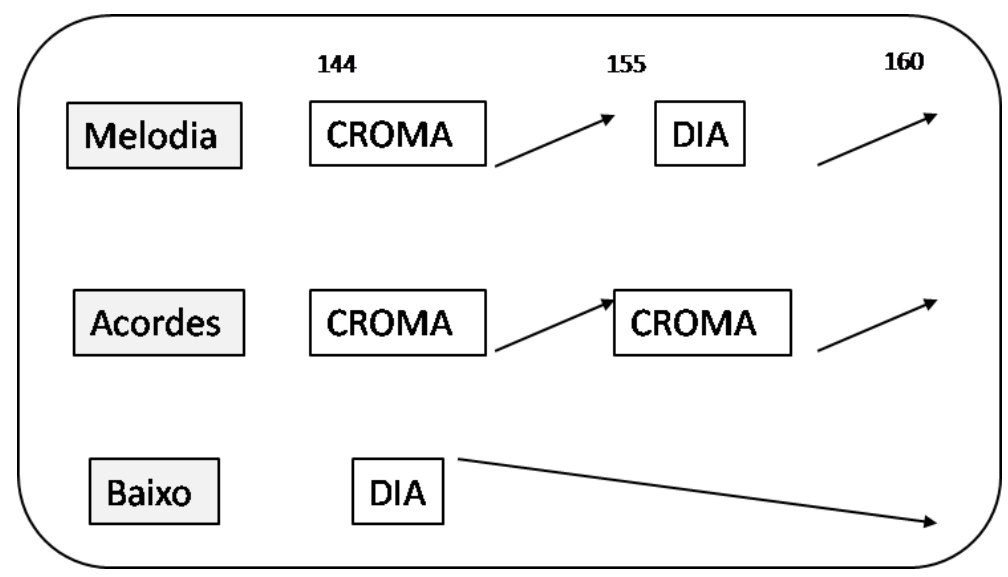

Figura 6 - "Allegro impetuoso", seção C, c. 144-160, oposições. Fonte: elaboração do autor.

O decréscimo da dinâmica denota uma atividade menos exaltada em relação às seções anteriores e antecede o retorno do tema (b) na seção B2. Todavia, essa retomada do tema (b) é transformada pelos eventos transcorridos desde sua aparição original. Nesse ponto, o tema ressurge (ainda nas cordas, em escrita alla breve) consideravelmente abreviado e em movimento sequencial ascendente, reproduzindo o procedimento da seção $C$ e denotando aumento na intensidade emocional. A figura do passus duriusculus (quase integral, faltando apenas o Mi natural) sinaliza a tópica do pianto (lamento) ${ }^{30}$; os sinos (c. 161-173) trazem significação simbólica mais evidente em relação à morte, expressa na narrativa literária (Fig. 7).
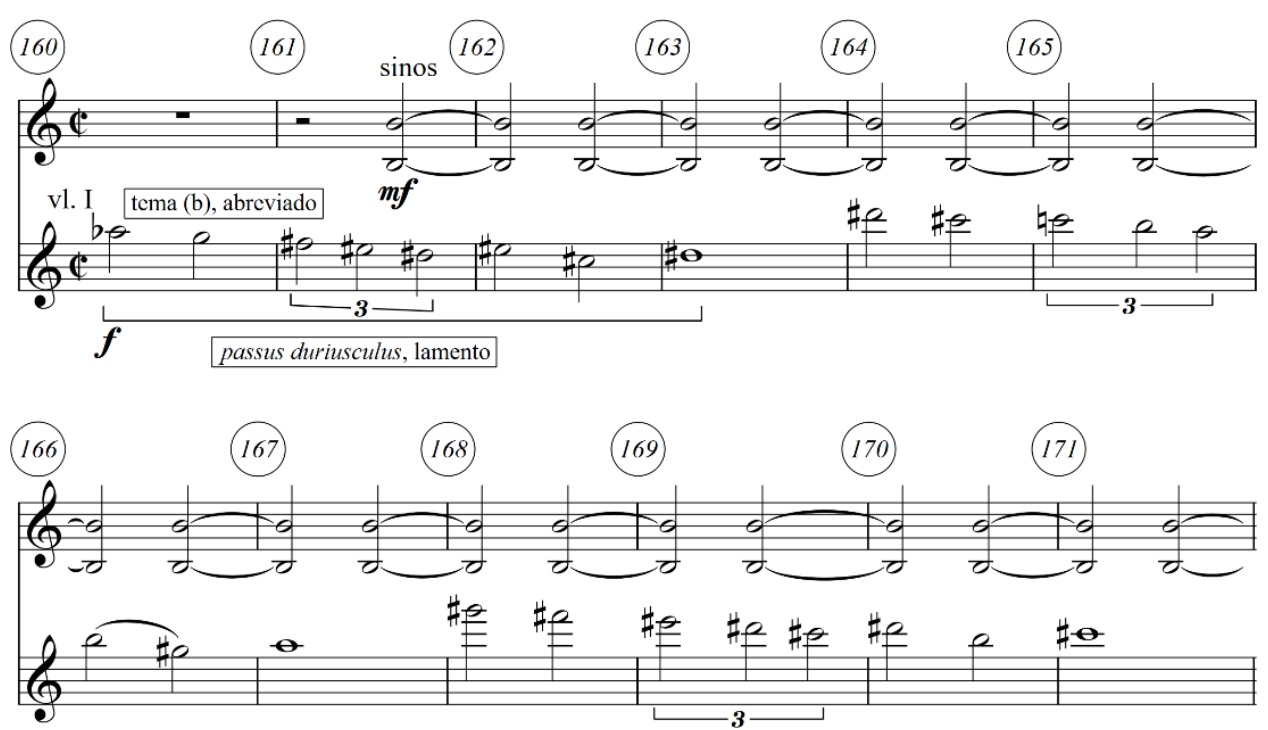

Figura 7 - "Allegro impetuoso", tema (b), c. 160-171. Redução (várias partes omitidas). Fonte: elaboração do autor.

A reaparição do "tema da vitória" (c. 197), com a maioria de suas características tópicas (mas ainda em modo menor), é marcante (Fig. 8). Há clara correlação com a 
narrativa escrita ("Entre os fumos da guerra, quando um pouco dissipados, aparece a figura da vitória, correndo por entre os combatentes, animando-os, nas mãos palma virente"); porém a resolução ainda é envolvida por outros processos disfóricos (como a cadência deceptiva no c. 204), culminando com a dramática coda ("Grandioso", ff) que opõe uma sequência triádica descendente a um pedal (Fá\#-Si) com reforço de tam-tam e sinos, com cadência em Si.

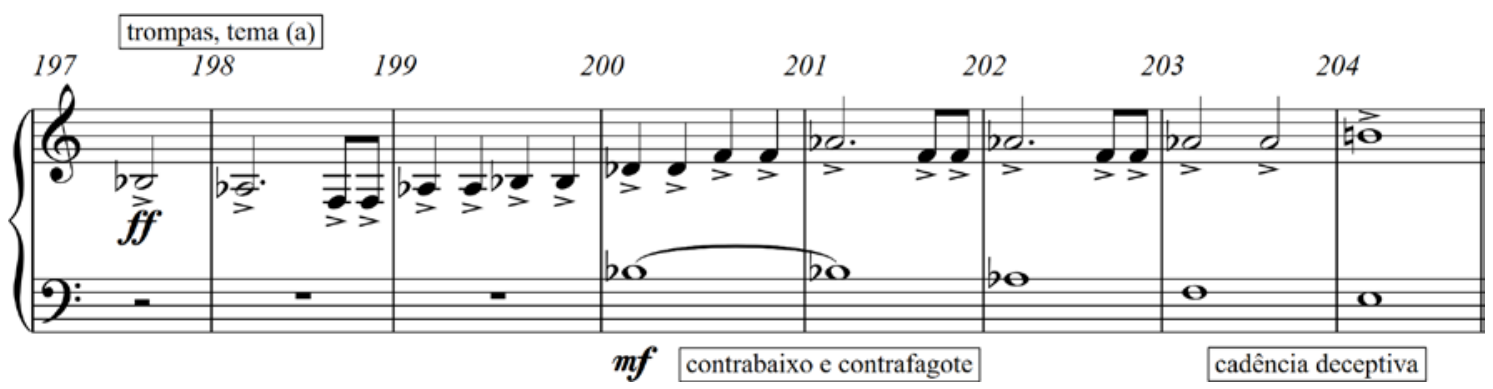

Figura 8 - "Allegro impetuoso", tema (a), c. 197-204. Redução (várias partes omitidas). Fonte: elaboração do autor.

\section{Sonata, ostinato, Debussy e Marselhesa: a trama temática do "Andantino"}

O segundo movimento é construído a partir de um ostinato rítmico sobre o acorde Lá-Fá\#-Si (cordas e trompa), estabelecendo um pulso irregular, resultante da justaposição das métricas ternária (3/4) e quaternária (4/4), que se mantém por toda a exposição (c. 1-58). O pulso irregular definido pelo ostinato gera a sensação de uma marcha disfórica ${ }^{31}$; a entrada do $\operatorname{tambor}^{32}$ (c. 31) amplia a significação rítmica, pois sugere a marcação do samba (se considerarmos a semínima inicial como síncopa) ou do bastão de ritmo indígena (se os ataques são considerados como pulsos).

O movimento está em forma sonata, com dois temas contrastantes. O primeiro deles é o tema cíclico (a), o "tema da vitória", apresentado pelos oboés (claramente uma disforia) em Fá\#, interpolado pelo ostinato e repetido pelos trompetes com surdina (outra disforia), em Dó\#33 (Fig. 9). As quartas paralelas com que os oboés enunciam o tema, e a entrada dos contrabaixos e cellos, com sons harmônicos (c. 5-8), são duas sinalizações tópicas associadas ao elemento indígena e/ou à natureza (SALLES, 2018, p. 271) ${ }^{34}$. Como

\footnotetext{
31 O compasso com sete tempos reúne assim tópicas tradicionalmente distintas: as "paixões exaltadas" do passo de marcha e as "paixões terrestres" das danças do estilo galante, cujo paradigma é o minueto (ALLANBROOK, 1983, p. 22).

32 O manuscrito da partitura, assim como o catálogo de obras do Museu Villa-Lobos, menciona apenas "tambor", mas a edição OSESP/ ABM prescreve um "tambor surdo", talvez para enfatizar o caráter rítmico de samba nesse ostinato em 7/4, subliminar para quem é familiarizado com variantes e deformações do gênero recorrentes na música popular brasileira. Luiz D'Anunciação oferece uma boa descrição do instrumento e suas propriedades, mas é vago ao indicar seu uso na música de Villa-Lobos "em algumas partituras", sem especificar as obras (ANUNCIAÇÃO, 2006, p. 74).

33 A relação tonal estabelecida na exposição do "Andantino", entre as notas iniciais do tema e sua reiteração, soa como alusão à sonata monotemática de Haydn. "O tema secundário baseado no tema primário produz o que é às vezes chamado de exposição (ou sonata) monotemática, embora na maioria dos casos seja um termo equivocado: após o encerramento essencial da exposição, Haydn costuma apresentar um novo tema na zona de conclusão" (HEPOKOSKI; DARCY, 2006, p. 136), tradução minha. Diferenças à parte, Villa-Lobos de fato apresenta um novo tema após a apresentação do tema inicial no padrão "tônica-dominante".
} 
não há correlação aparente entre essa tópica e o toque de fanfarra militar, o mais provável é que essas sinalizações afetem a interpretação do ostinato, que combina elementos presentes no modelo rítmico do Choros n 10, de acordo com Luiz D'Anunciação:

[...] Quando o fagote [no ensaio 5 do Choros $n$ ㅇ 10] anuncia o tema do coro que vai entrar no número 6 , Villa-Lobos inicia com o tímpano uma marcação muito simples, de dois em dois tempos, passando a seguir para o bombo [...]. No $12^{\circ}$ compasso o compositor define, com o bombo, a forma de marcar o pulso rítmico, à semelhança do bastão de ritmo das danças aborígenes. (ANUNCIAÇÃO, 2006, p. 41).

Como não há alusão ao indígena no programa literário, as marcações tópicas na narrativa musical transformam essa referência simbolicamente, caracterizando a efígie da vitória "correndo por entre os combatentes". A pureza de intenções do espírito da vitória, na versão villalobiana, se assemelha ao caráter idealizado do "bom selvagem", valendo-se de signos semelhantes para sua representação sonora.

A entrada no segundo tema (flauta e clarinete, em Si) é realizada sem preparação cadencial, aproveitando os acordes formados por trompas e cordas ${ }^{35}$, que progressivamente adensam o ostinato. O tema (b) tem perfil melódico sinuoso, em tercinas (Fig. 10), que lembra temas notáveis escritos por Debussy para as madeiras, como em "Fêtes" (2 movimento dos Nocturnes) e "De l'aube a midi sur la mer" (1 movimento de La Mer) (Fig. 11a e 11b).

\footnotetext{
exemplo em Debussy (DAY-O'CONNELL, 2009, p. 230); Webern, em suas palestras sobre a "música nova", evoca a teoria das cores de Goethe em associação com a série harmônica, para determinar como o material sonoro "é inteiramente fornecido pela natureza" (WEBERN, 1984, p. 26-37). Assim, uma alusão comum que compositores latino-americanos fazem à cultura dos povos ameríndios é o uso da escala pentatônica e a sons não temperados, como o uso de harmônicos nas cordas. Villa-Lobos emprega esse tipo de solução com frequência ao propor "paisagens sonoras" inspiradas pela floresta amazônica, em uma espécie de "metáfora estrutural" (SALLES, 2009, p. 193-195). Nesse sentido, o uso do intervalo de quarta, em movimento paralelo, se opõe ao de terça, como que afirmando a primazia do material sonoro bruto sobre o civilizado (associado com a tríade).

350 acorde que sustenta a transição direta entre os temas (a) e (b) é uma versão da tradicional sexta francesa (seria um trocadilho fazendo alusão ao tema debussiano e à França?), mais um exemplo da predileção villalobiana por acordes simétricos nos pontos de articulação formal.
} 

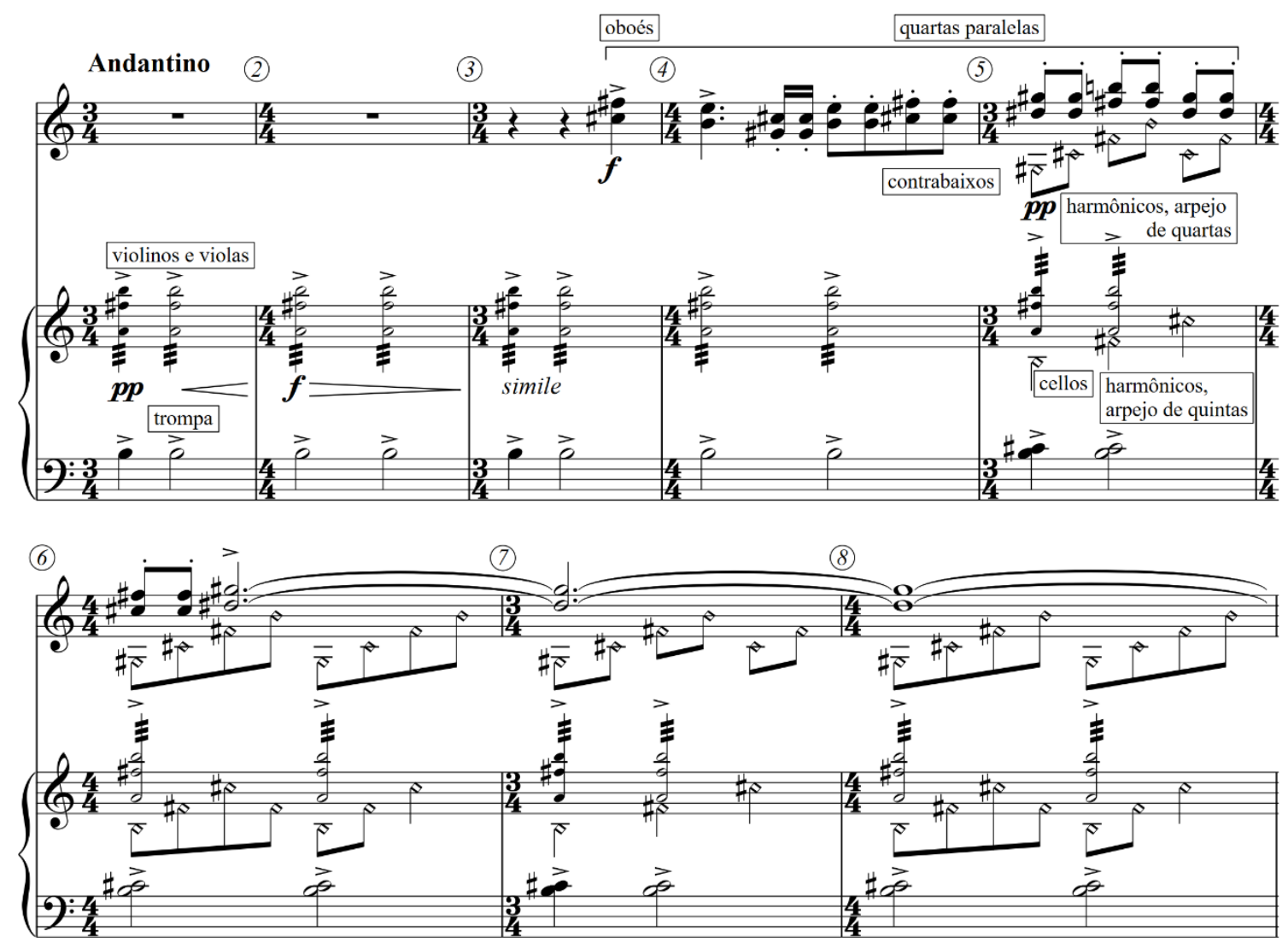

Figura 9 - Andantino", tema (a), c. 1-8. Redução. Fonte: elaboração do autor.

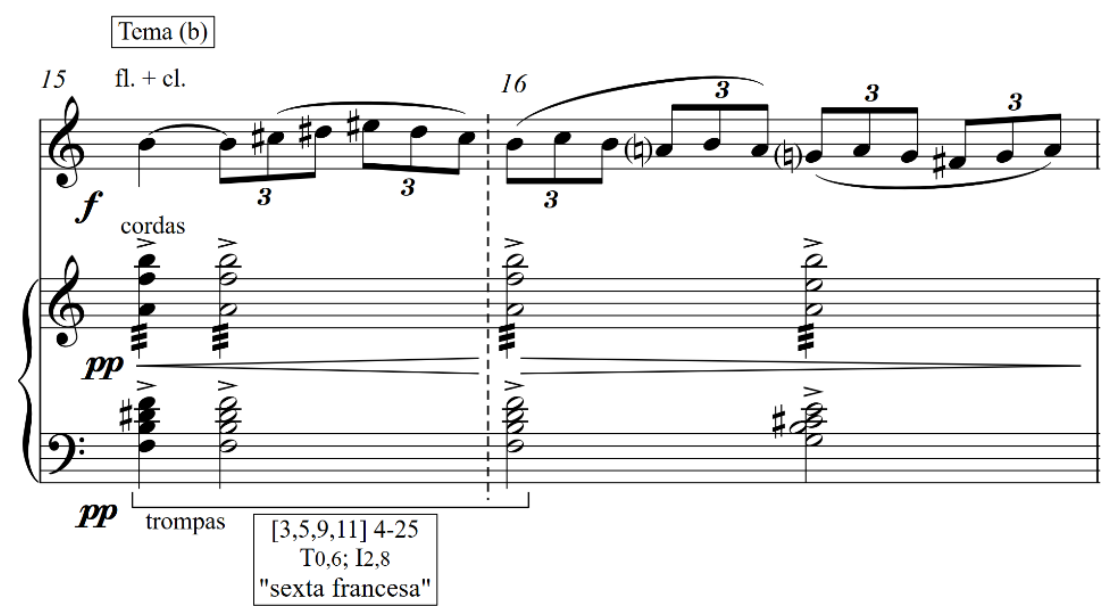

Figura 10 - "Andantino", tema (b), c. 15-16. Redução (várias partes omitidas). Fonte: elaboração do autor. 
a) 3

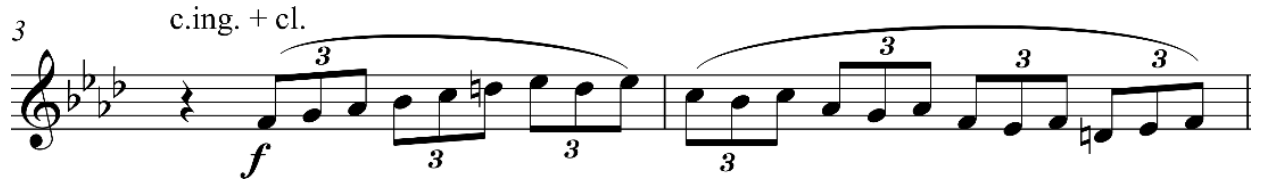

b)

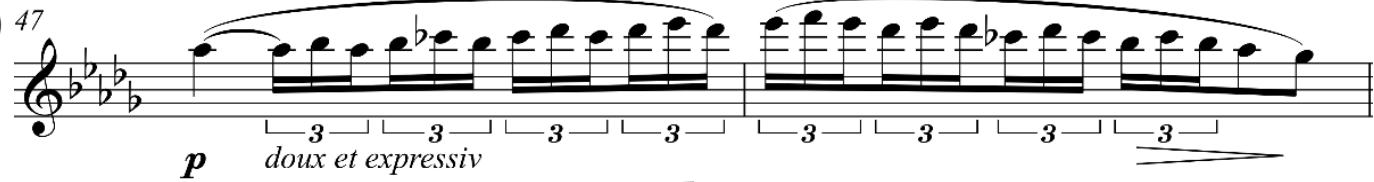

Figura 11 - Debussy: a) "Fêtes" (Nocturnes), corne-inglês e clarineta, c. 3-4; b) "De l'aube a midi sur la mer" (La Mer), flauta, c. 47-48 (ensaio $n^{\circ}$ 4). Fonte: elaboração do autor.

A chegada ao desenvolvimento é marcada pela citação da "Marselhesa"; esse ponto alinha a narrativa musical com o quinto verso do programa literário ("Corre à França, pede-lhe com as notas da Marselhesa, arraste a flor do universo"). As modalizações persistem: a métrica é mista, acompanhamento em 6/4, com cordas e tímpano sustentando uma nota pedal (Dó\#), e a melodia do hino francês em 2/2, enunciada pelas trompas em Mib menor ${ }^{36}$. O tema (b) do primeiro movimento da Sinfonia $n$ o 3 volta a ser citado, em seu exaltado estilo cantante (fanfarra interna, c. 66-78), porém em contraponto com um novo tema de caráter dançante (em staccato) nos violinos, flautas e oboés, sempre em colcheias (c. 66-83). Uma chamada nos metais, de caráter quase pastoral (c. 79-83), leva a uma intensificação do movimento de dança (a seção "Animato", ensaio no 6, c. 84-105). O tema staccato é reiterado quatro vezes, com pontuações violentas da percussão e dos metais quase à maneira de Stravinsky, culminando numa progressão descendente em tons inteiros (c. 102-105) que leva vertiginosamente para a recapitulação.

A recapitulação assume a textura rítmica estabelecida durante o desenvolvimento, em 12/8; o ostinato inicial não reaparece. Os temas são substancialmente modificados em caráter, com as fanfarras eufóricas assumindo seu valor tópico heroico-guerreiro, levadas ao paroxismo durante a transição para o segundo tema, com superposição de vários materiais temáticos e toques de clarim dialogando entre os diversos naipes. 0 tema (b) reaparece após uma breve intervenção das cordas, suavizando o frenesi dos metais. O segundo tema vem em 6/8, em andamento "Lento", ricamente ornamentado e com inflexões elegantes, talvez fazendo pensar nos versos que descrevem a vitória como "luminosa vestida de resplandecências, cingida de louros, de cabeça alta, de olhos abertos para o lado da luz". Após essa breve promessa de pacificação, um motivo de três notas, reunindo o trítono e o motivo do "suspiro" (Ré\#-Lá-Sol\#) ${ }^{37}$, convoca novamente os toques heroicos dos metais, até a cadência em fff sobre a nota Dó.

\footnotetext{
36 Outra alteração disfórica, já que o hino francês originalmente é em modo maior. A "Marselhesa" também é citada no movimento final da Sinfonia $n^{\circ}$ 3, em contraponto ao Hino Nacional Brasileiro.

37 A figura do pianto, representada por uma segunda menor descendente, tornou-se um motivo frequente no repertório canônico europeu, usado para expressar "lamento", sendo eventualmente associado com o passus duriusculus (MONELLE, 2000, p. 66-71).
} 


\section{Um adendo fora do tempo, mas dentro do tema}

O terceiro movimento é o que menos se relaciona com a narrativa literária, embora contribua para o adensamento da narrativa musical. O distanciamento do programa é compreensível, já que o movimento foi adicionado posteriormente ${ }^{38}$. Villa-Lobos buscava reforçar o discurso musical, talvez em resposta a alguma sugestão feita por d'Indy durante a conversa que tiveram em 1923. Ainda assim, o "Andante" tem conexões temáticas cíclicas que o integra perfeitamente com os demais movimentos e com a Sinfonia no $3^{39}$.

O caráter geral do "Andante" é de uma reflexão pesarosa, fora do tempo narrativo do programa, como se fosse o olhar de um observador angustiado, que embora dentro do conflito, percebe a possibilidade de vivenciar seu encerramento. A perspectiva mais individualizada da narrativa se deixa entrever na textura, na qual os solos são superpostos a uma camada densa de acompanhamento, que se mantém independente, talvez "indiferente", ao conteúdo expressivo da melodia. Com efeito, a melodia se espraia por entre prolongamentos, tercinas e ataques fora do tempo forte, simulando um tempo psicológico, enquanto o acompanhamento é realizado consistentemente em colcheias, estabelecendo uma marcação mais precisa e cronológica ${ }^{40}$.

O solo inicial do clarone emerge após o Dó tocado em fff por toda a orquestra no movimento anterior. A melodia desacompanhada realiza a bordadura, começando com Si-Dó ${ }^{41}$, seguido por um gesto descendente, que evoca o lamento (Fig. 12). O contrafagote surge com uma linha mais grave, sendo reforçado por trompa, saxofone barítono e depois pelo próprio clarone (c. 7-11). A semelhança com Amazonas é notável, onde a nota sustentada parece flutuar no acompanhamento ondulante, na região grave (SALLES, 2009, p. 36-38; 186-195). A melodia é transposta para outros instrumentos, aparecendo inicialmente no par corne-inglês e viola (solo); mais adiante a viola é substituída por um violino; finalmente, é apresentada com flauta, viola e violoncelo. Essas quatro versões do lamento, em sua progressão exaltada, delimitam a primeira seção.

\footnotetext{
38 A Sinfonia $n^{\circ} 3$ também recebeu um movimento lento adicional, antes do finale.

39 Há uma espécie de motivo unificador, usado em quase todos os temas da Sinfonia $n^{\circ} 4$ : o intervalo de $2^{\mathrm{a}}$ maior que inicia os temas de fanfarra e de $2^{\text {a }}$ menor, empregado na cabeça dos temas líricos.

40 Raymond Monelle faz um estudo da temporalidade tomando como referência principal a noção de tempo experimentado e tempo natural de Bergson (MONELLE, 2000, p. 86-92); Pierre Boulez propõe as categorias de tempo "amorfo ou liso" e "pulsante ou estriado" (BOULEZ, 1992, p. 112, grifos no original).

41 A edição OSESP/ABM apresenta uma nota errada no c. 2, que não é o prolongamento de Dó\# (soando como Si) no clarone, mas o semitom Dó\#-Ré (soando Si-Dó), de acordo com o manuscrito.
} 

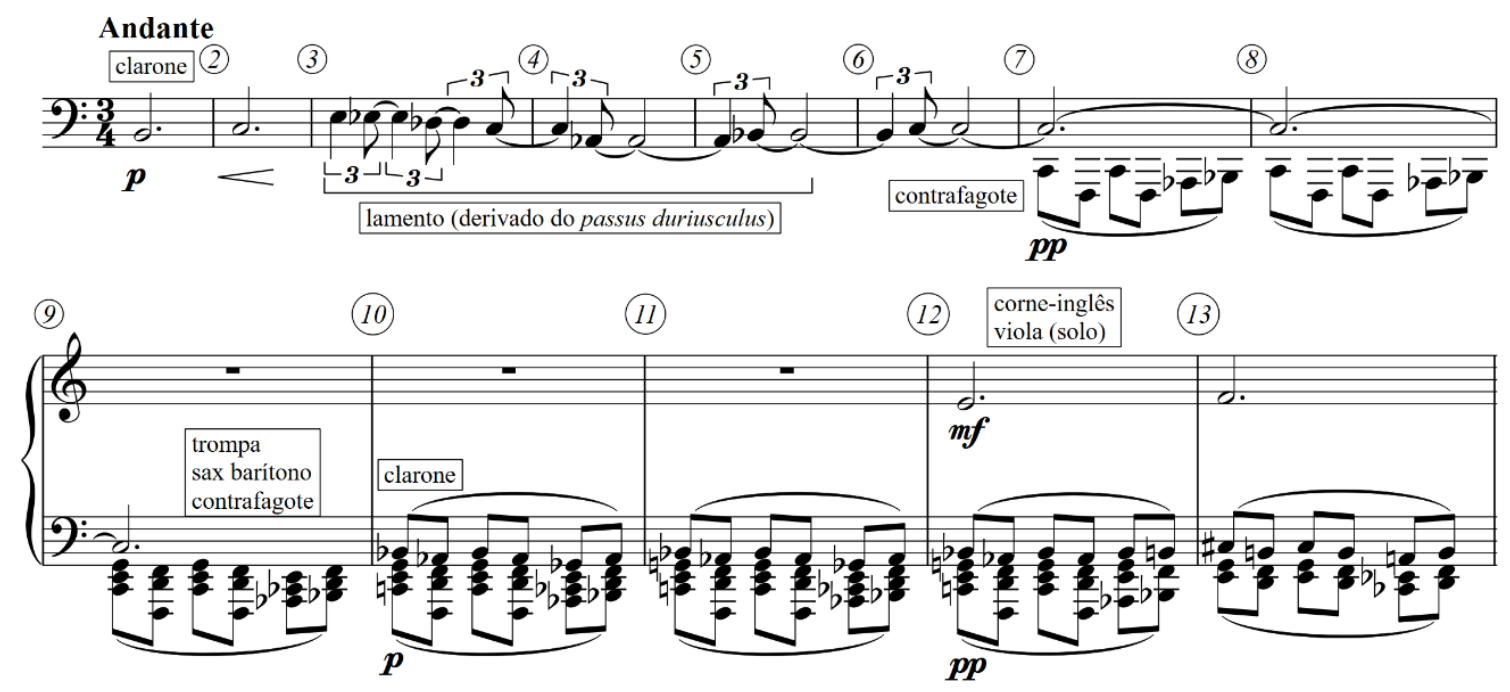

Figura 12 - "Andante", c. 1-13. Fonte: elaboração do autor.

A forma geral é livre: A-B-C-Coda, denotando a proximidade estilística com obras compostas durante a década de 1920. O quadro abaixo oferece uma descrição das partes, com destaque para a "Marcha fúnebre" na seção C e a citação do tema da Sinfonia no 3 na coda (Quadro 2).

\begin{tabular}{|c|c|c|}
\hline COMP. & SEÇÃO & DESCRIÇÃO \\
\hline $1-40$ & $A$ & $\begin{array}{l}\text { Quatro apresentações do tema (a), com pequenas variantes } \\
\text { 1-11: clarone, solo expressivo e desacompanhado (Si), seguido pelo acompa- } \\
\text { nhamento em movimento ondulatório por contrafagote e demais madeiras. } \\
\text { 12-21: corne-inglês e viola solo, Mi, sobre o acompanhamento das madeiras. } \\
\text { 22-34: corne-inglês e violino solo, com configuração diatônica, Lá. } \\
\text { 35-40: "Adagio", flauta, viola e cello, sobre acorde sustentado nas trompas. Sib. }\end{array}$ \\
\hline $41-64$ & $B$ & $\begin{array}{l}\text { Seção binária } \\
\text { 41-47: "Poco più mosso", em 3/2. Tema (b), violinos em estilo cantante com } \\
\text { movimento ascendente, acompanhamento em palíndromo (clarone, fagote e } \\
\text { contrafagote), pedal em Sol\# (tímpano e contrabaixos); 47-54: tema (b) flauta } \\
\text { e clarineta em Ré (47-51), passando para os primeiros violinos em Lá\# (49-54). } \\
\text { 55-64: tema (c), violinos alla breve, em ff, sobre ostinato de trompetes (em } \\
\text { semínimas) e madeiras (em tercinas de colcheia, com reforço da celesta). }\end{array}$ \\
\hline $65-75$ & C & $\begin{array}{l}\text { Marcha fúnebre, "Lento", em 4/2. } \\
\text { 67-70: melodia diatônica (corne-inglês, clarone, fagote); ostinato em duas } \\
\text { camadas, uma harmônica, com cordas (depois harpas) e contrabaixos, outra } \\
\text { com a nota pedal Láb, tocada no contratempo por piano, celesta e sinos. 72- } \\
\text { 75: mudança de compasso, para 12/8; melodia nas cordas, Sib. }\end{array}$ \\
\hline $76-80$ & Coda & $\begin{array}{l}\text { "Più lento", em 12/8. } \\
\text { 73-75: melodia dobrada por oboé e cordas. } \\
\text { 76-80: citação do tema cíclico da Sinfonia no } 3 \text { (tema da guerra), tocado em } \\
\text { ff pelas cordas. Cadência sobre o acorde com sobreposição de dois acordes } \\
\text { simétricos: C7M e Am7; porém a resultante é assimétrica. }\end{array}$ \\
\hline
\end{tabular}

Quadro 2 - "Andante", estrutura formal. Fonte: elaboração do autor.

A "Marcha fúnebre" remete a uma passagem semelhante em caráter, ouvida no primeiro movimento, com pedal em Láb, dobrado por sinos, celesta e piano, no contratempo. Porém, ao invés da marcha exaltada, impulsionada pela melodia alla breve nos violinos e o acompanhamento em colcheias nas violas e violoncelos do movimento 
inicial, o caráter fúnebre no terceiro movimento é mais "espiritualizado", com o acompanhamento alla breve. A melodia diatônica, tocada por corne-inglês, clarone e fagote é quase "pastoral"42; sua continuação (oboé e violinos) mantém essa atmosfera, interrompida com brusquidão pelas cordas com o "tema da guerra" (da Sinfonia $n^{\circ}$ 3), que leva à cadência.

\section{A progressiva afirmação da vitória}

O quarto movimento ("Lento - Allegro") também tem estrutura livre e rapsódica como o anterior, embora mais longo e variado: A-B-C-D-E-F-G-Coda (Quadro 3). Trata-se de uma realização bastante subavaliada na produção villalobiana, já que apresenta procedimentos mais audaciosos que as texturas de Amazonas e tão complexos como certas passagens dos Choros $n \div 8$ ou $n \div 10$, obras aclamadas e reconhecidas pela crítica.

Seu caráter afirmativo, estabelecido desde o rufo de tímpano e os toques iniciais dos trompetes, assume o mesmo tom assertivo das quatro estrofes finais do poema de Dória, que anunciam em celebração: "- É a vitória". A narrativa musical recebe o suporte da estrutura cíclica que traz a solução dos conflitos acumulados nos temas e entre eles para o finale. Marianne Wheeldon observa um aspecto importante, "tomando emprestado a retórica de d'Indy, podemos dizer que esses temas [do movimento final] assumem características antagônicas e se envolvem em uma batalha pela supremacia" (WHEELDON, 2005, p. 666). Essa disputa se revelaria tanto na disposição tópica dos temas, onde as fanfarras se movem do polo "disfórico" para o "eufórico", enunciando os aspectos heroicos e guerreiros da vitória em sua plenitude no movimento final; em oposição, os temas líricos, com característica de "lamento", tendem a perder sua corporeidade, mantida como recordação emotiva das perdas durante a guerra, confortada pela esperança de chegada à paz trazida pela vitória.

42 É como se Villa-Lobos tivesse dissociado o caráter "exaltado", preservado nos temas (b) e (c) (c. 41-64) do caráter "espiritual" dessa marcha fúnebre. No primeiro movimento essas marcações eram simultâneas e reforçadas pela figura do passus duriusculus. 


\begin{tabular}{|c|c|c|}
\hline COMP. & SEÇÃO & DESCRIÇÃO \\
\hline $1-38$ & $A$ & 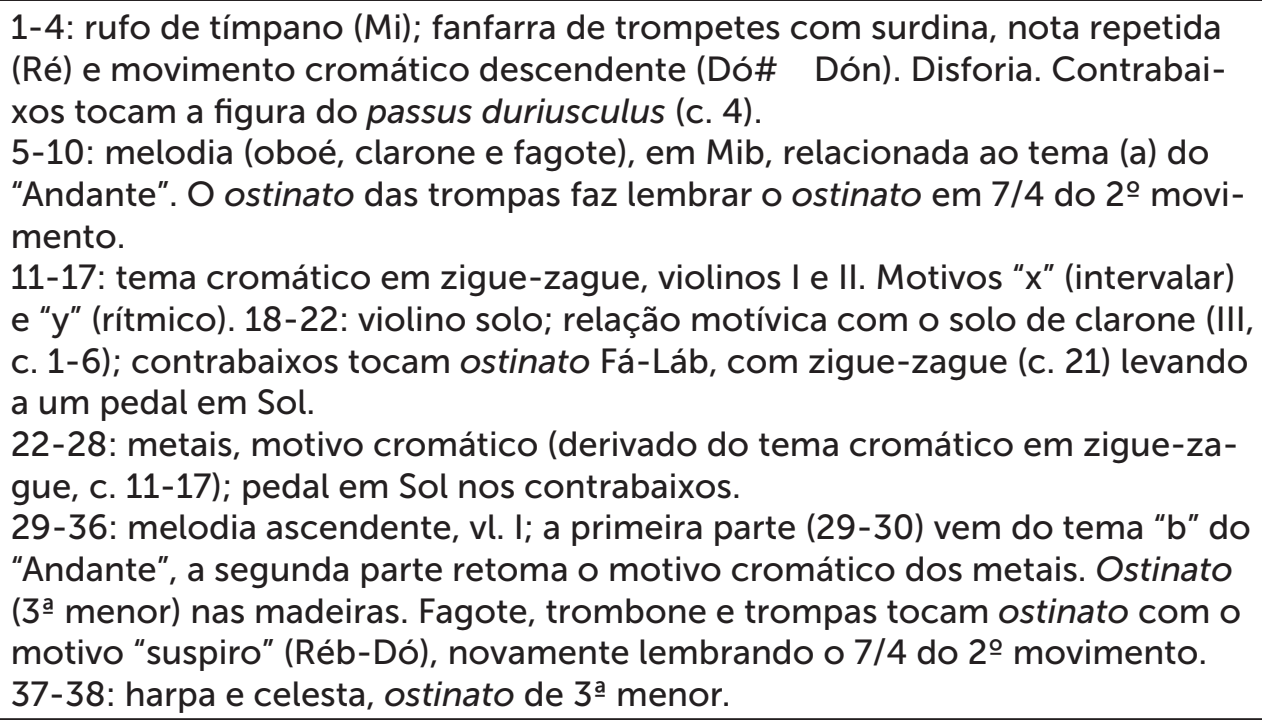 \\
\hline $39-81$ & B & $\begin{array}{l}\text { 39-51: "Lento", 6/4. Pedal em Dó\#; melodia na flauta. O ostinato (3a menor) } \\
\text { passa a ser conduzido por harpa e celesta. Outra camada de ostinato, com } \\
\text { harmônicos nos violinos I, faz lembrar a textura do solo de flauta de Uirapuru. } \\
\text { 52-57: "Assai moderato", } 12 / 8 \text {. Ostinato nas madeiras, em semicolcheias; me- } \\
\text { lodia oboé e clarone, em Ré. } \\
\text { 58-71: ostinato no conjunto interno, simultâneo à melodia de oboé e clarone; } \\
\text { violinos I assumem a melodia (c. } 62 \text {-ss), no momento de maior densidade, } \\
\text { com várias camadas de ostinatos; o ostinato em semicolcheias passa para a } \\
\text { harpa, sendo reforçado pelo violino II (c. } 62-\text {-ss.). } \\
\text { 72-81: melodia (vl. I) e ostinato "conjunto interno"; piccolo, assume a linha } \\
\text { da requinta; as violas reforçam o ostinato em semicolcheias nas cordas, que } \\
\text { segue até o final da seção. }\end{array}$ \\
\hline $82-119$ & C & $\begin{array}{l}\text { "Allegro", 3/4. Motivo cíclico (Sinfonia no 3), na trompa; melodia violinos; 104- } \\
\text { 119: tema (b) ("Pastoral") do I movimento da Sinfonia no 3, com aumentação. }\end{array}$ \\
\hline $120-251$ & D & $\begin{array}{l}\text { "Allegro vivo", 2/4. 120-140: Tema cíclico (a) (tema da vitória): fanfarra de } \\
\text { trompetes (Lá); 141-155: fanfarra disfórica: madeiras (Lá); } 156-187: \text { metais. } \\
\text { 188-238: melodia vl. I, com caráter predominantemente pentatônico. } \\
\text { 188-197: 5-35 [7,9,11,2,4]; 198-201: 5-35 (02479); } 202-205: 5-34 \text { [7,9,11,1,4]; } \\
\text { 206-217: Ré Lídio, 7-35; melodia diatônica ascendente, crescendo. 228-233: } \\
\text { 5-35 [2,4,6,9,11]; 238-251: mudança de textura, com notas longas; a cadência } \\
\text { (246-251) promove a transformação de A\#m7 (FN 4-26, 16) no tetracorde as- } \\
\text { simétrico 4-22, processo análogo a uma semicadência no estilo villalobiano. }\end{array}$ \\
\hline $252-381$ & $E$ & $\begin{array}{l}\text { "Prestíssimo", com caráter de "Scherzo" (as indicações de subseção valem } \\
\text { apenas para esta seção e não tem relação com as seções A, B e C anteriores): } \\
\text { 256-271: A1; 272-300: B1; 301-316: A2; 317-325: B2; 326-381: C, motivo de 3a } \\
\text { maior descendente e 2 }{ }^{\text {a }} \text { menor ascendente. }\end{array}$ \\
\hline $382-400$ & $F$ & $\begin{array}{l}\text { "Adagio" (cortejo majestoso), 4/2. Fanfarra eufórica, tema cíclico "a" ("vitó- } \\
\text { ria"), trompas e saxhornes, com contraponto no baixo (tuba, etc.), em Sol. } \\
\text { Soa quase como um dobrado, sem a marcação de pratos e bumbo. 385-ss.: } \\
\text { os demais instrumentos da fanfarra (trombone, trompa e cornet) repetem o } \\
\text { tema em cânone. }\end{array}$ \\
\hline $401-448$ & G & $\begin{array}{l}\text { "Allegro", 3/4. Retomada do tema de fanfarra do início do I movimento, nas } \\
\text { madeiras (Sol). Contraponto no xilofone. }\end{array}$ \\
\hline $449-474$ & Coda & $\begin{array}{l}\text { "Allegro (vitorioso)", 2/4. Tema cíclico (a) ("vitória"), fanfarra em Si. Marcação } \\
\text { da percussão (bumbo e pratos). Cadência na díade Dó-Sol. }\end{array}$ \\
\hline
\end{tabular}

Quadro 3 - "Lento - Allegro", estrutura formal. Fonte: elaboração do autor. 
A trajetória triunfal, no entanto, é estabelecida gradualmente. Nos compassos iniciais pode-se apreciar a grande densidade de elementos narrativos e temáticos recolocados em ação (Fig. 13). A fanfarra inicial dos trompetes é modulada pelas surdinas; enquanto os trompetes I e II atacam a nota Ré, os trompetes III e IV tocam o movimento cromático descendente (Dó\#-Dón), que evoca o motivo do "suspiro", dois elementos disfóricos. Nos contrabaixos, a figura do passus duriusculus (de Mib a Sib, c. 4) evoca o "lamento" de outras passagens, em movimentos anteriores. Os acentos rítmicos, enfatizando as semínimas iniciais, fazem lembrar o ostinato em 7/4 do segundo movimento, lembrança que permeia toda a seção "A" (c. 1-38); a melodia do oboé (c. 5), dobrado por clarone e fagote, retoma algo do terceiro movimento.
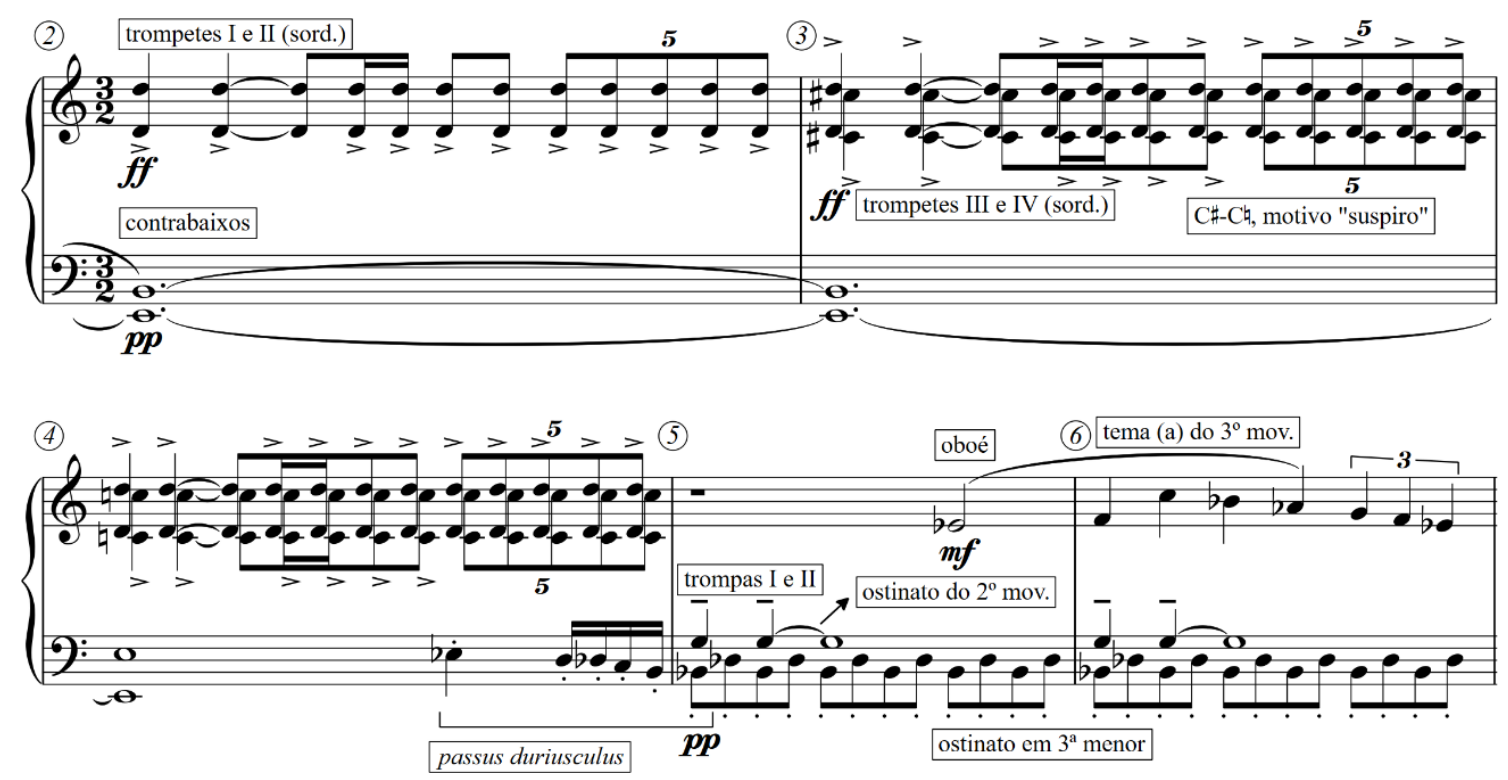

Figura 13 - "Lento-Allegro", c. 2-6. Redução (partes omitidas). Fonte: elaboração do autor.

Há ainda relações temáticas complexas, com caráter de desenvolvimento, reunindo melodias e fragmentos melódicos aparentemente desconexos. O tema cromático em zigue-zague (violinos II e violas; violinos I) está relacionado motivicamente com o coro de metais (c. 22-25); o motivo rítmico (y) por retrogradação; o motivo (x) por transposição livre, com perfil melódico semelhante. Como resultante, o coro dos metais é a fusão dos dois motivos apresentados separadamente pelas cordas (Fig. 14, a, b, c), relacionados ao motivo expressivo do "suspiro". A terminação nos violinos I (c. 16-17) evoca o passus duriusculus ${ }^{43}$, em versão disfórica pelo registro brilhante e acentuações de dança. 
(1)

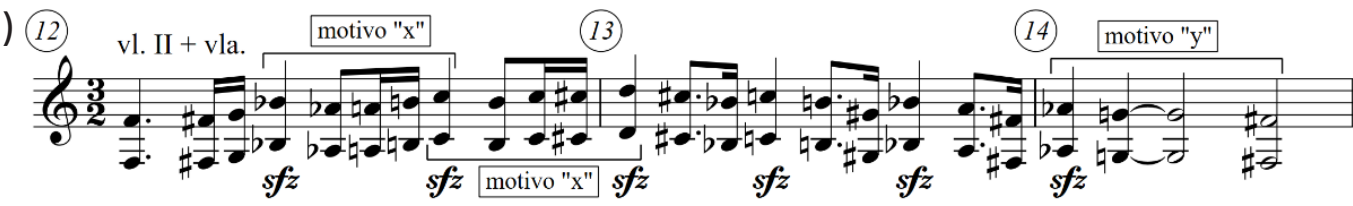

(15)

(16)

(17)

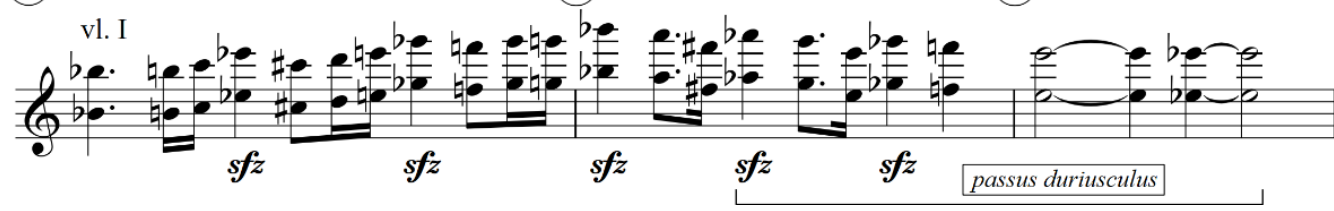

b)

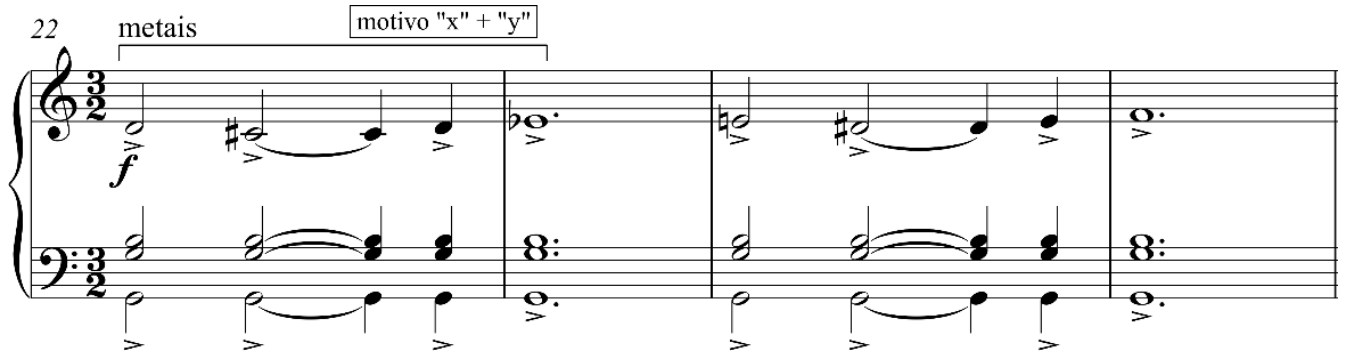

c)

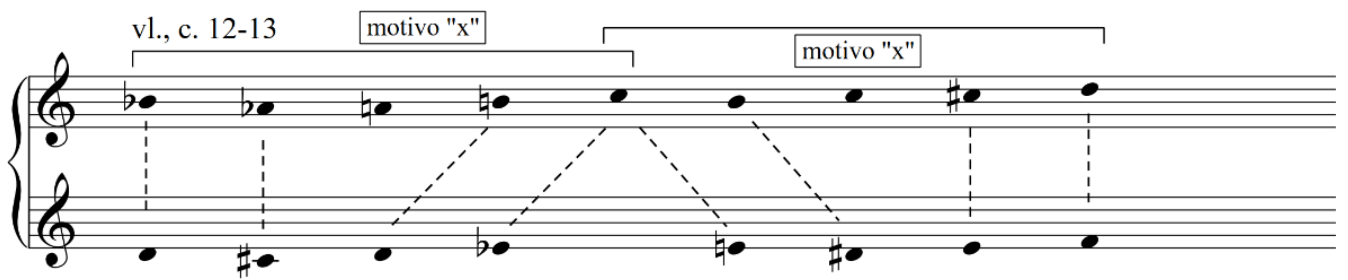

tpt., c. 22-25

Figura 14 - "Lento-Allegro": a) c. 12-17, tema cromático, em zigue-zague nos violinos; b) c. 22-25, coro dos metais; c) comparação entre os temas de violinos e metais. Fonte: elaboração do autor.

O uso de sons harmônicos nas cordas, timbre que marca o início do segundo movimento, reaparece na textura que envolve o solo de flauta (c. 39-51), à maneira de passagem semelhante ouvida em Uirapuru. Esse entreato "naturalista" reforça a tentativa de restaurar a inocência perdida ao longo dos anos de guerra, mas esse pensamento é tingido pela fanfarra nas trompas com surdinas (c. 45-49), que irrompem no centro da textura, retomando o caráter guerreiro lançado no início pelos trompetes.

Isso leva a uma seção em 12/8 ("Assai moderato") onde ocorre um adensamento da simultaneidade entre camadas concorrentes. As madeiras tocam figuras em semicolcheias, os demais instrumentos em colcheias, gerando um tecido ondulatório sobre o qual oboé e clarone entoam melodia expressiva. Quando essa textura se estabelece, temos a primeira participação do "conjunto interno" (formado por requinta, saxofones soprano, alto, tenor, barítono, triângulo, pandeiro, pratos e bumbo), tocando uma melodia com caráter de dança, em staccato, no estilo "turco" (dada a marcação da percussão). Esse material é superposto à melodia de clarone e oboé, com acompanhamento das linhas de ostinato nas harpas, madeiras e trompa (Fig. 15). O efeito se assemelha a certas passagens ouvidas tipicamente na música de Charles Ives, como em "The Fourth of July", terceiro movimento de A Symphony: New England Holidays (estreada em Paris 
em 1932) e Central Park in The Dark (1906), mas faz lembrar também do início do Choros $n^{\circ}$ 6, do próprio Villa-Lobos.

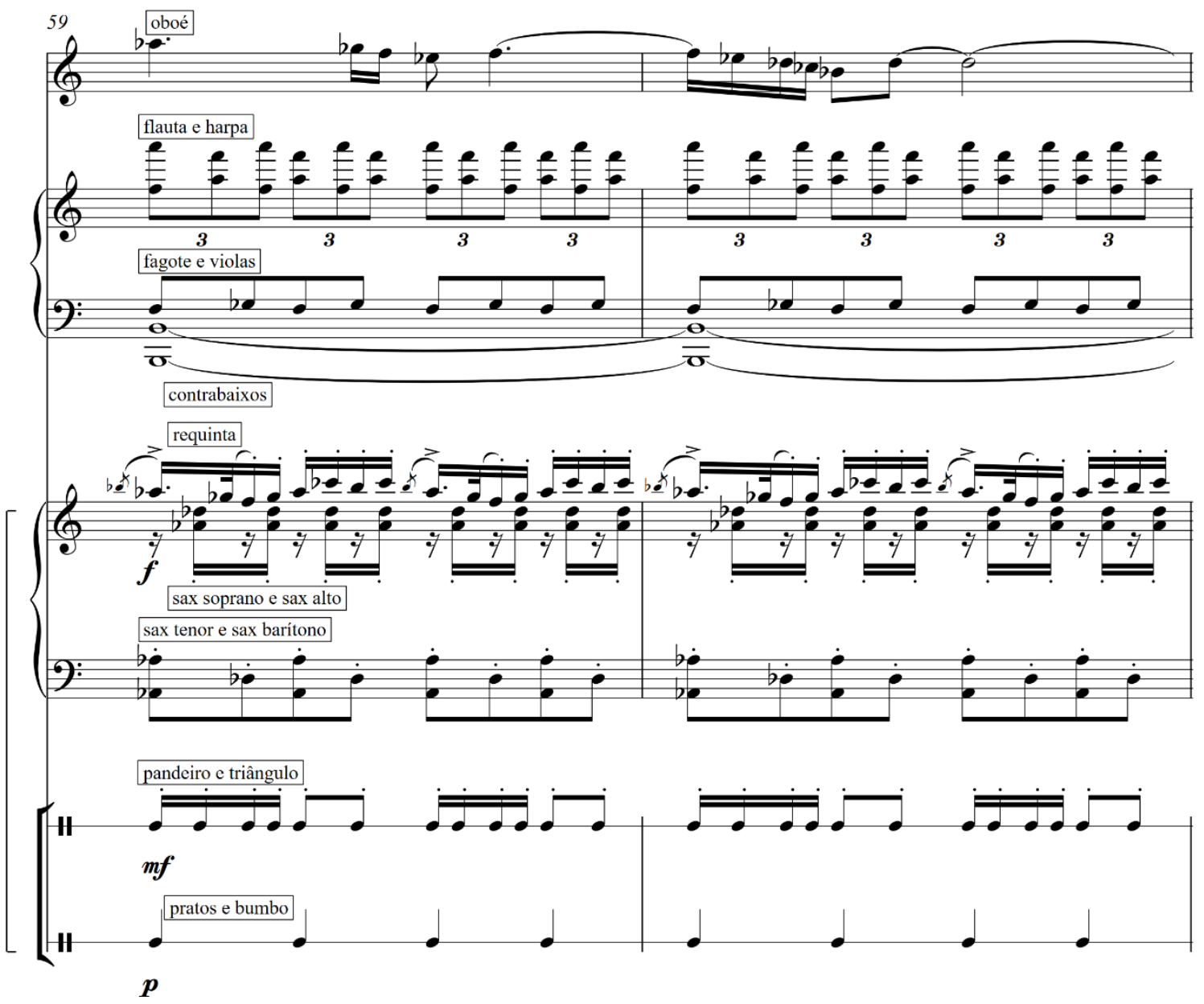

Figura 15 - "Lento-Allegro", c. 59-60, superposição de camadas e entrada do conjunto interno. Redução (partes omitidas). Fonte: elaboração do autor.

A melodia do oboé passa para os primeiros violinos (c. 62), no momento de maior densidade textural, quando a figuração tocada pelo conjunto interno se converte em ostinato; mais adiante, alguns fatores alteram significativamente o caráter da passagem: as trompas III e IV marcam o baixo em Sol-Ré, os clarinetes reforçam a alternância entre os acordes de Sol e Ré maior (c. 76), a melodia da requinta passa a ser dobrada pelo piccolo, os primeiros violinos deixam a melodia e passam a tocar uma linha de ostinato em semicolcheias com alternância de acentuações e staccato, como uma dança rústica em 12/8; a partir desse ponto, vemos emergir o caráter pastoral (c. 77-81) ${ }^{44}$, sugerido no $2^{\circ}$ e 3 movimentos. A evocação campestre persiste na seção seguinte, onde o tema pastoral da Sinfonia $n$ o 3 é retomado euforicamente pelos violinos no "Allegro" da seção C.

A alegria despreocupada dessas evocações campestres e pueris é interrompida pela chegada ao acorde de Si meio-diminuto ("Allegro vivo", c. 120, ensaio 9); a harpa

44 A caracterização pastoral, nesse ponto da Sinfonia $n^{\circ}$ 4, é completa: "A métrica gentil da siciliana em 12/8 ou 6/8 é fundamental para o espírito pastoral" (MONELLE, 2006, p. 215); Monelle destaca o uso da trompa como instrumento pastoral, alusão comum no repertório sinfônico romântico (ibidem, p. 100-107). Villa-Lobos demonstra ter conhecimento de toda a convenção em torno desse tópico. 
toca um arpejo de Ré menor com sétima que serve como base para mais uma fanfarra disfórica, iniciada por clarinetes e sax-alto, e incorporada pelos trompetes. Isso dá início a uma sequência de enunciados do tema cíclico (a), com caráter progressivamente mais enfático, respondido cerimoniosamente pelo tímpano. Os violinos apresentam um tema pentatônico de caráter exaltado (c. 188-237), pontuado por fanfarras dos metais, chegando a um motivo descendente nos segundos violinos (c. 238-243) que, sobre um pedal em Lá\#, realiza uma "semicadência villalobiana"45.

Diante das várias ideias apresentadas de modo mais ou menos completo ao longo da obra, com ênfase nas propriedades guerreiras do tema da vitória, a seção seguinte ("Prestissimo", ensaio 16) tem características de scherzo ${ }^{46}$. Sua violenta ação rítmica, registros extremos, cortes, golpes de percussão etc. vão ainda mais além do recorte stravinskiano desencadeado pela citação da "Marselhesa" no segundo movimento. É uma das realizações mais fantásticas da escrita orquestral villalobiana antes da década de 1920. O caráter burlesco do scherzo se contrapõe às afirmações ingênuas ou otimistas (de cunho pastoral), ou heroicas (de cunho militar) que a antecederam, adicionando certa dose de ironia diante das perdas e sofrimentos passados. Mas esse sentimento amargo é superado pela reapresentação do tema cíclico, em sua versão triunfante, indicada na partitura como um "cortejo majestoso" (Fig. 16).

Adagio (cortejo majestoso)
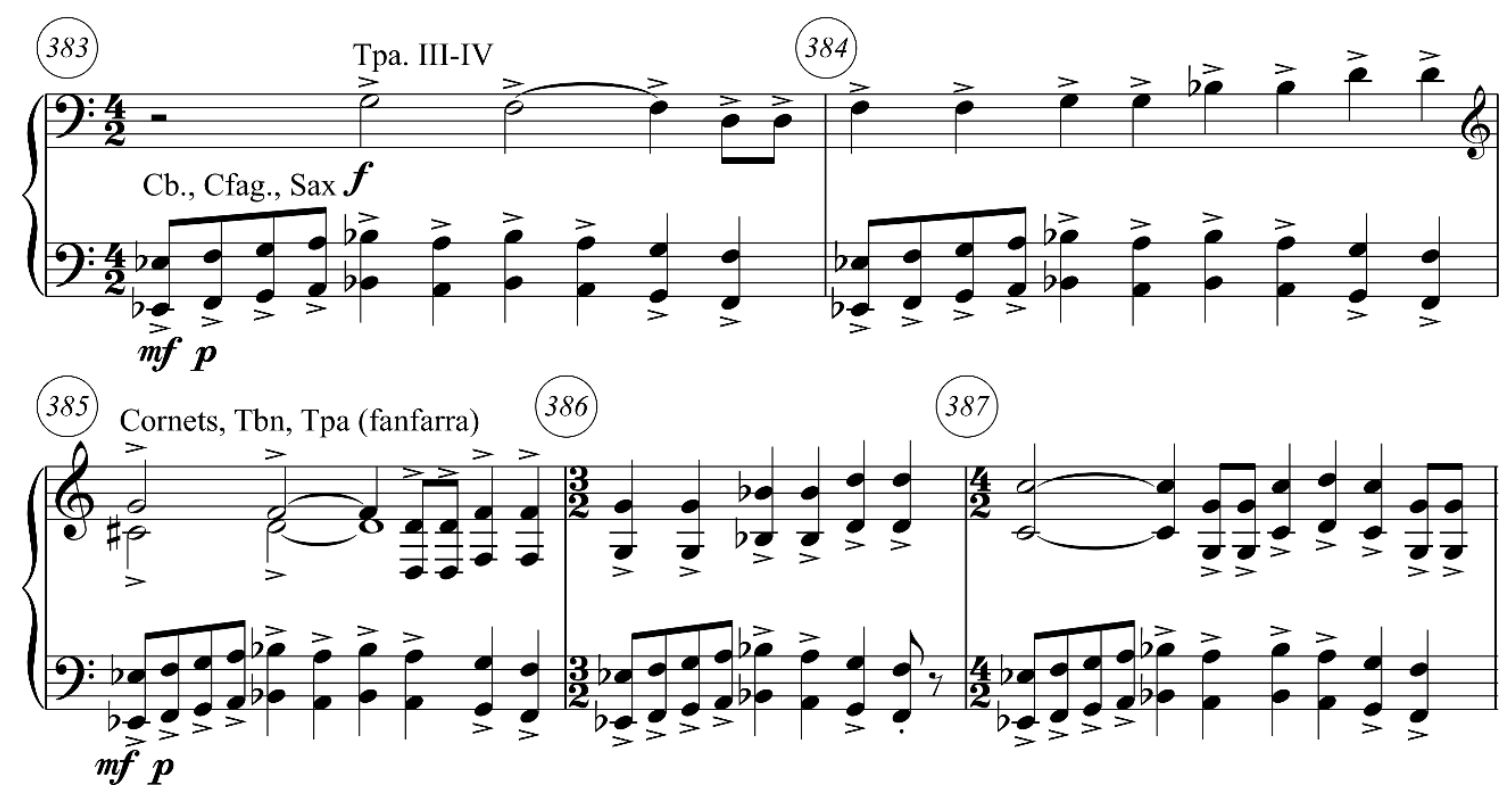

Figura 16 - "Lento-Allegro", c. 383-387, fanfarra eufórica. Redução (várias partes omitidas). Fonte: elaboração do autor.

A fanfarra inicial reaparece, em versão aumentada ritmicamente, anunciando a chegada na coda; esta última aglutina todas as forças orquestrais, em paroxismo que

\footnotetext{
45 Refiro-me ao uso peculiar do acorde simétrico como repouso, típico do estilo harmônico desenvolvido por Villa-Lobos para caracterizar uma espécie de "cadência autêntica", e suas variantes expressivas como a semicadência ou a cadência deceptiva; nos c. 246-252 ocorre o enlace entre o acorde simétrico de Lá\# menor com sétima (FN 4-26, 16) e um tetracorde assimétrico (FN 4-22); esse evento equivale a uma passagem observada no primeiro movimento do Quarteto de Cordas n 15 (SALLES, 2018, p. 177-178), caracterizando a analogia com a semicadência tonal. 
reconvoca o tema cíclico sobre o pedal em Dó. Villa-Lobos simplifica a textura, atribuindo notas longas em acordes sustentados pelo naipe de fanfarra e conjunto interno; o tema é entoado nos metais, com dobramento pelas madeiras. A cadência é na díade Dó-Sol, em ffff.

\section{Conclusão}

A Sinfonia no 4 de Villa-Lobos agrega elementos formais e expressivos na elaboração de uma narrativa musical. A obra pode ser escutada independentemente do programa literário, mas se torna especialmente significativa se ouvida em diálogo com o texto. Ao longo desta análise podem-se identificar diversas unidades temáticas cuja função extrapola o mero papel predeterminado por um modelo formal. Essas unidades têm também significação cultural e parecem propositalmente convocadas a provocar uma escuta não reduzida somente a relações sonoras "puras". Embora essa seja a expectativa normalmente atribuída ao gênero do poema sinfônico e seus correlatos instrumentais como a música para balé e teatro, ou no território amplo da música vocal (cantata, canção, ópera, música religiosa etc.), a música de Villa-Lobos se situa muitas vezes no limite entre a expressão sonora bruta e o desejo de atribuir identidade aos impulsos sonoros por meio de uma retórica fundada na cultura.

Ao longo desta análise foram apresentadas algumas tópicas musicais atuantes como unidades culturais, as quais se correlacionam com funções estruturais que coordenam a forma, como temas, transições, introduções, cadências e codas. Os elementos temáticos circulam pela obra, estabelecendo pontes entre os movimentos e com a Sinfonia $n$ ㅇ 3, à qual está indissoluvelmente associada (Fig. 17); é uma pena que a Sinfonia $\mathrm{n}$ 5 esteja perdida, pois pode-se supor que as relações temáticas entre as três sinfonias resultariam em um quadro muito interessante.

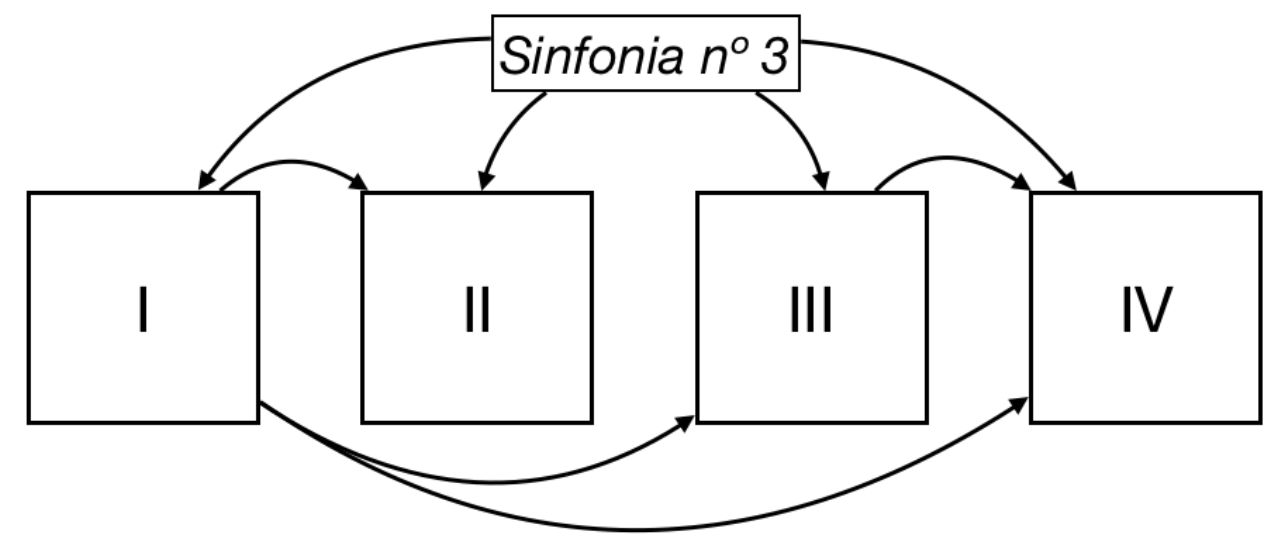

Allegro impetuoso

Andantino

Andante

Lento-Allegro

Figura 17 - Sinfonia $n^{\circ}$ 4, distribuição cíclica dos temas e sua relação com a Sinfonia nº 3. Fonte: elaboração do autor.

As tópicas tomaram parte nesta análise como unidades culturais dentro de uma narrativa. Como observa Byron Almén, "a tópica é expressivamente estática", enquanto 
por oposição, "a narrativa é expressivamente dinâmica" (ALMÉN, 2008, p. 75) ${ }^{47}$. Portanto, a estratégia adotada para a construção da narrativa analítica depende da correlação das unidades formais com seu papel na estrutura e a comparação com os paradigmas que permeiam a escuta. Não basta identificar e quantificar, por exemplo, as tópicas de guerra distribuídas ao longo da Sinfonia $n$ o 4. É necessário buscar uma interpretação quanto a sua potência expressiva de acordo com os elementos sonoros que as caracterizam com maior ou menor intensidade, sua transvaloração. O aspecto qualitativo da tópica oscila entre os polos "eufórico" (onde seus caracteres são mais enfatizados) e "disfórico" (onde a caracterização é enfraquecida pela ausência ou mudança de alguma marcação), termos propostos por Raymond Monelle (2000, p. 45-63). Assim, pode-se elaborar um quadro com as tópicas identificadas e interpretadas nesta análise (Quadro 4).

\begin{tabular}{|c|c|c|c|}
\hline TÓPICA & TIPO & EUFORIA & DISFORIA \\
\hline \multirow[t]{2}{*}{$\begin{array}{l}\text { Militar } \\
\text { (guerra) }\end{array}$} & Fanfarra & $\begin{array}{l}\text { Tocadas pelos metais, em modo } \\
\text { maior, forte. }\end{array}$ & $\begin{array}{l}\text { Tocada por instrumento não } \\
\text { pertencente ao naipe de metais, } \\
\text { modo menor, suavizada (dinâmi- } \\
\text { ca, surdina). }\end{array}$ \\
\hline & Marcha & $\begin{array}{l}\text { Ritmo binário, andamento médio-rá- } \\
\text { pido, dinâmica forte. }\end{array}$ & $\begin{array}{l}\text { Alteração métrica, andamento } \\
\text { lento ou rápido demais, dinâmi- } \\
\text { ca suave. }\end{array}$ \\
\hline \multirow[t]{2}{*}{ Pastoral } & Melodia & $\begin{array}{l}\text { Tocada por flauta, oboé ou trompa; } \\
\text { caráter cantabile; modo maior. }\end{array}$ & $\begin{array}{l}\text { Mudança de instrumento, cará- } \\
\text { ter grave, modo menor. }\end{array}$ \\
\hline & Dança & $\begin{array}{l}\text { Leveza; ritmo composto, } 12 / 8 \text { ou } \\
6 / 8 ; \text { acompanhamento evocando } \\
\text { água ou vegetação. }\end{array}$ & Peso excessivo; ritmo simples. \\
\hline \multirow[t]{2}{*}{$\begin{array}{l}\text { Lamento } \\
\text { (Pianto) }\end{array}$} & Suspiro & $\begin{array}{l}\text { Intervalo descendente de segunda } \\
\text { menor; dinâmica suave. }\end{array}$ & Dinâmica forte. \\
\hline & $\begin{array}{l}\text { Passus durius- } \\
\text { culus }\end{array}$ & $\begin{array}{l}\text { Preenchimento cromático do inter- } \\
\text { valo de quarta justa; região grave; } \\
\text { dinâmica suave; legato. }\end{array}$ & $\begin{array}{l}\text { Modificação no intervalo, ausên- } \\
\text { cia de algum passo cromático; } \\
\text { região brilhante; dinâmica forte; } \\
\text { acentuação. }\end{array}$ \\
\hline \multirow[t]{2}{*}{$\begin{array}{l}\text { Natureza ou } \\
\text { indígena }\end{array}$} & Dança ritual & $\begin{array}{l}\text { Alternância de staccato e acentua- } \\
\text { ção; melodia por graus conjuntos de } \\
\text { caráter diatônico ou pentatônico; } \\
\text { quartas (ou quintas) superpostas; } \\
\text { ostinati. }\end{array}$ & $\begin{array}{l}\text { Legato; saltos melódicos e cro- } \\
\text { matismo; terças ou sextas; perda } \\
\text { do caráter repetitivo do ostinato. }\end{array}$ \\
\hline & $\begin{array}{l}\text { Paisagem } \\
\text { sonora }\end{array}$ & $\begin{array}{l}\text { Uso de harmônicos, glissandos, sons } \\
\text { não temperados; quartas ou quintas } \\
\text { superpostas }\end{array}$ & Não se aplica. \\
\hline \multirow[t]{2}{*}{$\begin{array}{l}\text { Estilo can- } \\
\text { tante }\end{array}$} & Melodia & $\begin{array}{l}\text { Âmbito limitado, simulando melodia } \\
\text { vocal; legato; tocado preferencial- } \\
\text { mente pelas cordas (vibrato). }\end{array}$ & Extensão extrema; staccato. \\
\hline & Alla breve & $\begin{array}{l}\text { Escrita em valores longos (mínimas, } \\
\text { semibreve); legato. }\end{array}$ & $\begin{array}{l}\text { Valores mais curtos, tercinas; } \\
\text { staccato. }\end{array}$ \\
\hline
\end{tabular}

Quadro 4 - Tópicas musicais e possíveis transvalorações na Sinfonia n 4. Fonte: elaboração do autor.

47 Tradução minha, grifos no original, que diz: "topic is expressively static" e "narrative is expressively dynamic". 
A lista acima não pretende ser exaustiva, mas ilustra os pontos mais recorrentes na Sinfonia $n=4$ nesta análise. Dentre as tópicas discutidas, chama atenção a ocorrência de alusões ao indígena e à natureza, um universo tópico estranho ao repertório sinfônico europeu, que foi progressivamente levado à sala de concertos por músicos brasileiros como Carlos Gomes, Francisco Braga e Villa-Lobos ${ }^{48}$. A tópica indígena (ou da "natureza") tem afinidade com a tópica pastoral, porém não se caracteriza pela leveza rítmica e fluida em métricas compostas ${ }^{49}$, enfatizando primitivismo e rusticidade com mais peso, geralmente com auxílio de ostinati.

Outro aspecto a ser considerado são as eventuais superposições entre tópicas distintas, por vezes gerando significados resultantes dessas oposições (tropos).

A Sinfonia no 4 (A Vitória), tem um papel maior na trajetória de Villa-Lobos do que a historiografia tem contemplado. É uma obra ambiciosa, que articula elementos da tradição europeia com processos que o compositor desenvolveu em seu segundo período criativo nos anos 1920. Sintomaticamente, o incidente que impediu sua estreia marcou um ponto negativo na carreira do compositor, que o encobriu habilmente, respondendo criativamente às críticas e promovendo a estreia em 1922. O que poderia ter sido a "queda" do compositor, representou uma reviravolta em sua trajetória artística, desencadeada pouco tempo depois com sua ida a Paris em 1923. Também é notável que seja a única sinfonia gravada pelo autor nos registros feitos em Paris nos anos 1950.

\section{Referências}

ALLANBROOK, Wye J. Rhythmic Gestures in Mozart: Le Nozze di Figaro and Don Giovanni.

ALMÉN, Byron. A Theory of Musical Narrative. Bloomington, IN: Indiana University Press, 2008.

BOULEZ, Pierre. A música hoje 2. Tradução de Geraldo G. de Souza. São Paulo: Perspectiva, 1992 [1985].

CAPLIN, William. Classical Form: A Theory of Formal Functions for the Instrumental Music of Haydn, Mozart, and Beethoven. New York; Oxford: Oxford University Press, 1998.

CORREIO DA MANHÃ. Morreu o autor dos 'Pingos e Respingos': com o falecimento de Bastos Tigre perdem as nossas letras o último humorista sério do Brasil. Rio de Janeiro:

\footnotetext{
48 A referência a tópicas indígenas e naturais não são exclusivas da música brasileira, mas comuns na música dos países andinos na América do Sul. No entanto, na música europeia ocorrem tópicas semelhantes na tendência primitivista do modernismo, cuja porta de entrada é Stravinsky.

49 Monelle (2006, p. 238) observa como a Siciliana em 12/8 representava a tópica pastoral no Barroco e como foi suplantada pelo 6/8 no Classicismo, após Haydn; ambas as métricas, no entanto, permanecem representativas da tópica pastoral.
} 
3 ago. 1957. Disponível em: http://memoria.bn.br/DocReader/Hotpage/HotpageBN. aspx?bib=089842_06\&pagfis=79742\&url=http://memoria.bn.br/docreader\#. Acesso em 14 fev. 2020.

CORREIO DA MANHÃ. A ópera lzaht de Villa-Lobos. Rio de Janeiro, 10 jun. 1921. Disponível em: http://memoria.bn.br/DocReader/Hotpage/HotpageBN. aspx?bib=089842_03\&pagfis $=6512 \&$ url=http: $/ /$ memoria.bn $\cdot$ br $/$ docreader\#. Acesso em 22 fev. 2020.

DÓRIA, Luís G. d'Escragnolle. A Victoria. In: Jornal do Commercio, Rio de Janeiro, 31 jul. 1919. Acesso em 15 nov. 2019. Disponível em: http://memoria.bn.br/docreader/ DocReader.aspx?bib=364568_10\&pagfis $=42505$.

ENYART, John W. The Symphonies of Heitor Villa-Lobos. Dissertation for the degree of Doctor of Philosophy in Music, University of Cincinnati, 1984.

FAGUNDES, Luciana P. A recepção do Embaixador da Paz: um concerto de gala para Epitácio Pessoa. Revista Brasileira de Música, Rio de Janeiro, v. 31, n. 1, p. 163-186, 2018.

FAGUNDES, Luciana P. Uma República em festa: a visita dos reis belgas ao Brasil (1920). Dissertação de Mestrado em História Social. Rio de Janeiro: Universidade Federal do Rio de Janeiro, Instituto de Filosofia e Ciências Sociais, 2007, p. 177-180.

GAMA, Zadig M. F.; MELLO, Celina Maria M. de. Luís Gastão d'Escragnolle Dória: um polígrafo das letras brasileiras. Soletras, Dossiê n. 34, p. 329-353, 2017. DOI: 10.12957.

GUÉRIOS, Paulo. Heitor Villa-Lobos: o caminho sinuoso da predestinação. 2. ed. Curitiba: Edição do autor, 2009.

GUIMARÃES, Luiz et al. Villa-Lobos: visto da plateia e na intimidade (1912/1935). Rio de Janeiro: Arte Moderna, 1972.

GREIMAS, Algirdas J. Sobre o sentido II: ensaios semióticos. Tradução de Dilson F. da Cruz. São Paulo: Nankin; Edusp, 2014 [1980].

HEPOKOSKI, James; DARCY, Warren. Elements of Sonata Theory: Norms, Types, and Deformations in the Late-Eighteenth-Century Sonata. Oxford; New York: Oxford University Press, 2006.

DAY-O'CONNELL, Jeremy. Debussy, Pentatonicism, and the Tonal Tradition. Music Theory Spectrum, v. 31, n. 2, p. 225-261, 2009. 
D'INDY, Vincent. Cours de composition musicale. Paris: Durand, 1909.

KATER, Carlos. Villa-Lobos de Rubinstein. Latin American Music Review, v. 8 n. 2, p. 246-253, 1987.

MARIZ, Vasco. Heitor Villa-Lobos, compositor brasileiro. 11. ed. Belo Horizonte: Itatiaia, 1989.

MIGALHAS. Homenagem a Manoel Bastos Tigre. ISSN 1983-392X. Endereço eletrônico: https://www.migalhas.com.br/quentes/188672/homenagem-a-manoel-bastos-tigre. 21 out. 2013. Acesso em 14 fev. 2020.

MONELLE, Raymond. The Musical Topic: Hunt, Military, and Pastoral. Bloomington, IN: Indiana University Press, 2006.

MONELLE, Raymond. The sense of Music. Princeton and Oxford: Princeton University Press, 2000.

MOORTELE, Steven Vande. Two-Dimensional Sonata Form: Form and Cycle in SingleMovement Works by Liszt, Strauss, Schoenberg, and Zemlinsky. Leuven: Leuven University Press, 2009.

PEPPERCORN, Lisa. Villa-Lobos, The Music: An Analysis of His Style. London; White Plains, NY: Kahn \& Averill; Pro/Am Music, 1991.

RATNER, Leonard. Classic Music: Expression, Form, and Style. New York: Schirmer, 1980.

SALLES, Paulo de Tarso. Os quartetos de cordas de Villa-Lobos: forma e função. São Paulo: Edusp, 2018.

SALLES, Paulo de Tarso. Villa-Lobos, processos composicionais. Campinas: Ed. Unicamp, 2009.

STOÏANOVA, Ivanka. Manuel d'analyse musicale: variations, sonate, formes cycliques. Paris: Minerve, 2000.

TARASTI, Eero. A Theory of Musical Semiotics. Bloomington, IN: Indiana University Press, 1994.

WEBERN, Anton. O caminho para a música nova. Tradução de Carlos Kater. São Paulo: Novas Metas, 1984. 
WHEELDON, Marianne. Debussy and La Sonate Cyclique. The Journal of Musicology, v. 22, n. 4, p. 644-679, 2005.

ZANON, Fabio. Heitor Villa-Lobos: Sinfonia n 3 - "A Guerra" e nํ 4 - "A Vitória". Livreto do CD de Isaac Karabtchevsky (regência) com a Orquestra Sinfônica do Estado de São Paulo. Manaus: Movieplay, 2013. 